$\mathrm{DOE} / \mathrm{PC} / 88818--10$

DE92 004520

TWO-STAGE, CLOSE COUPLED

CATALYTIC LIQUEFACTION OF COAL

TENTH QUARTERLY REPORT FOR THE PERIOD

1 JANUARY 1991 - 31 MARCH 1991
A.G. COMOLLI
E.S. JOHANSON
S.V.PANVELKER
G.A. POPPER
R.H. STALZER

WORK PERFORMED UNDER CONTRACT

DE-AC22-88PC88818

HYDROCARBON FESEARCH, INC.

100 OVERLOOK CENTER, SUITE 400

PRINCETON, NEW JERSEY 08540

AUGUST 1991

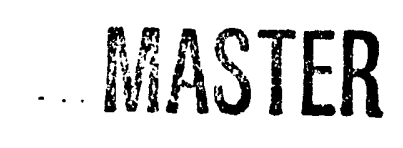

DISTRIBUTION OF THIS DOCUMENT IS UNLIMITED 
TWO-STAGE, CLOSE COUPLED

CATALYTIC LIQUEFACTION OF COAL

TENTH QUARTERLY REPORT FOR THE PERIOD

1 JANUARY 1991 - 31 MARCH 1991
A.G. COMOLLI
E.S. JOHANSON
S.V. PANVELKER
G.A. POPPER
R.H. STALZER

WORK PERFORMED UNDEI $\{$ CONTRACT

DE-AC22-88PC88818

HYDROCARBON RESEARCH, INC.

100 OVERLOOK CENTER, SUITE 400

PRINCETON, NEW JERSEY $08540^{\circ}$ 


\title{
PRINTED IN THE UNITED STATES OF AMERICA
}

\author{
AVAILABLE FROM: \\ National Technical Information Center \\ U. S. Department of Energy \\ 5285 Port Royal Road \\ Springfield, Virginia 22161
}

\begin{abstract}
This report was prepared as an account of work sponsored by the United States Government. Neither the United States nor the United States Department of Energy, nor any of their employees, makes any warranty, expressed or implied, or assumes any legal liability or responsibility for the accuracy, completeness, or usefulness of any information, apparatus, product, or process disclosed, or represents that its use would not infringe privately owned rights. Reference herein to any specific commercial product, process, or service by trade name, mark, manufacturer, or otherwise, does not necessarily constitute or imply its endorsement, recommendations, or favoring by the United States Government or any agency thereof. The views and opinions of authors expressed herein do not necessarily state or reflect those of the United States Government or any agency thereof.
\end{abstract}

\section{DISCLAIMER}

\begin{abstract}
This report was prepared as an account of work sponsored by an agency of the United States Government. Neither the United States Government nor any agency thereof, nor any of their emplnyees, makes any warranty, express or implied, or assumes any legal liability or responsibility for the accuracy, completeness, or usefulness of any information, apparatus, product, or process disclosed, or represents that its use would not infringe privately owned rights. Reference herein to any specific commercial product, process, or service by trade name, trademark, manufacturer, or otherwise does not necessarily constitute or imply its endorsement, recommendation, or favoring by the United States Government or any agency thereof. The views and opinions of authors expressed herein do not necessarily state or reflect those of the United States Government or any agency thereof.
\end{abstract}




\section{TABLE OF CONTENTS}

\section{PAGE}

ABSTRACT

SUMMARY 2

INTRODUCTION ..........................................................................

TASK 2 -LABORATORY SCALE STUDIES …..................................... 4

Evaluation of Catalyst Sulfide Maintenance Agents .................... 4

Impact of $\mathrm{CO}_{2}$ Upon Liquefaction ........................................... 5

TASK 3 -BENCH-SCALE STUDIES ……............................................ 6

Run CC-12 (227-70) Catalyst Rejuvenation ............................... 6

Run CC-13 (227-71) $\mathrm{CO}_{2}$ and Light Distillate Slurrying .............. 21

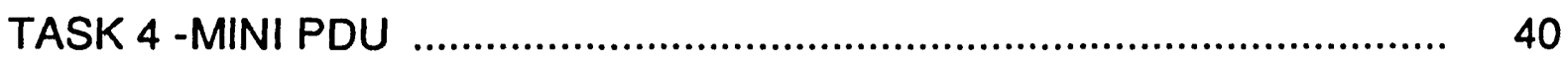

Preparations - Filter ............................................................. 40

TASK 5 -TECHNOLOGY ASSESSMENT .......................................... 41

Modelling ........................................................................... 41

TASK 6 -ADMINISTRATION .............................................................. 44 


\section{LIST OF TABLES}

PAGE

1 ANALYSES OF FEED COAL FOR RUN CC-12

2 PREPARATION OF REJUVENATED CATALYST FOR RUN CC-12 - ANALYSES OF CATALYSTS ………………….............. 11

3 METALS BALANCE ACID WASHING AND REGENERATION.... 12

4 RUN CC-12 - RUN PLAN - CATALYST REJUVENATED SHELL S-317

5 LIQUEFACTION PERFORMANCE RUN CC-12

6 LIQUEFACTION PERFORMANCE RUN CC-12 AND RUN CC-1

7 CTSL OPERATIONS - REJUVENATED AND FRESH

8 ANALYSES OF FEED COAL FOR RUN CC-13

9 INSPECTION LIGHT SOLVENT SLURRY OIL FOR RUN CC-13

10 RUN CC-13 (227-71) OPERATIONAL SUMMARY

11 LIQUEFACTION PERFORMANCE RUN CC-13 


\section{ABSTRACT}

This quarterly report covers activities of the Two-Stage, Close-Coupled Catalytic Liquefaction of Coal program during the period January 1, - March 31, 1991, at Hydrocarbon Research, !nc., in Lawrenceville and Princeton, New Jersey. This DOE contract period is from October 1, 1988 to December 31, 1991.

The overall purpose of the program is to achieve higher yields of better quality transportation and turbine fuels and to lower the capital and prnduction costs in order to make the products from direct zoal liquefaction competitive with other fossil fuel products.

The quarterly report covers work on Microautoclave Testing, Bench-Scale Illinois No. 6 and New Mexico coals experimentation, Technology Assessment, Modelling and scheduling. 


\section{SUMMARY}

The first calendar quarter of 1991 was a productive period with two bench-scale studies, microautoclave support studies, mini-PDU preparations, and process modelling.

Several catalyst presulfiding agents and $\mathrm{CO}_{2}$ effects upon liquefaction were evaluated in microautoclave scale tests. Dimethyl disulfide will be used for the PDU scale-up based on the results of these tests and prior data. Carbon dioxide appears to enhance coal conversion; however, gas and water yields are increased indicating possible water gas shift-hydrocarbon synthesis reactions.

In the bench-scale studies, the rejuvenation of spent catalyst with acid and carbon burn-off produced catalytic activity akin to freslı catalyst in a 12 day evaluation.

A 14 day study of the addition of high concentrations of $\mathrm{CO}_{2}$ to a sub-bituminous coal liqueiaction system demonstrated the occurrence of water gas shift hydrocarbon synthesis reactions and conversely higher coal conversions and distillate yields with high hydrogen consumplions.

Preparations for a PDU Demonstration Run on Black Thunder Mine coal are underway. The British Coal Filtration Process will be used for solid separation.

The results of microautoclave scale tests on Illinois, Ohio and Black Thunder Mine coals were reviewed and statistically analyzed to provide a sound basis for kinetic interpretation. 


\section{INTRODUCTION}

The studies conducted in this, the tenth quarterly report of Contract No. DE-AC22-88PC88818, are reported by task and in sequence.

Task 1 is the Management Plan and is complete. Task 2 is for Laboratory Studies arid includes microautoclave and microreactor work. Task 3 is for Bench-Scale studies and in this report covers results of Runs CC-12, and 13. Task 4 is for Mini PDU Scale-up. Task 5 is the Technical Assessment, including Modelling, Design and Economics. Task 6 is Administration.

The contract period was from October 1, 1988, to September 30,1991, and is being extended to December 31, 1991. 


\section{TASK 2 - LABORATORY STUDIES}

\section{EVALUATION OF CATALYST SULFIDE MAINTENANCE AGENTS}

A series of microautoclave tests were carried out evaluating candidate agents for maintaining the sulfide state of the catalyst in the PDU, specifically, TNPS (di-Tertiary Nonyl Polysulfide), DMDS (Dimethyl Disulfide), and elemental Sulfur.

A total of 16 tests were done at $825^{\circ} \mathrm{F}, 2000$ psig hydrogen pressure, using Presulfided Shell S-317 catalyst, and a coal liquefaction distillate as carrier, with 1 weight of carrier per weight of catalyst. The sulfide maintenance agent was equivalent to 0.05 and 0.10 grams per gram of catalyst, at test times of 15 and 45 minutes. The following conclusion were drawn:

Sulfiding Effectiveness - Product catalysts from each test had a higher sulfur content than in the presulfided catalyst charged (which contained $6.54 \%$ sulfur, equivalent to $90 \%$ sulfiding to $\mathrm{MoS}_{2}$ and NiS) by a factor of up to 1.2. The highest level of sulfur was obtained in the longer tests with the higher proportion of sulfiding agent with each agent. Although the very highest degree of sulfur addition was obtained in a DMDS test, all three agents had essentially same performance in this respect.

Utilization of the Agents - Some unconverted sulfur remained with solvent phase after the tests with the sulfiding agents. With TNPS this proportion was $13-16 \%$ of the sulfur in the agent, essentiaily the same level for all of the tests. With DM:DS this proportion was $6-10 \%$ of the sulfur in the agent, unrelated to the test time, but perhaps at the lower proportion with the lower concentration of the agent. With elemental sulfur this proportion was $9-14 \%$ of the sulfur in the agent, with no re!lation to concentration of the agent, but perhaps lower for the long residence time tests.

Light Gas Yields - Light Gas yialds with the TNPS and elemental sulfur agents were marginally higher than was obtained in background tests without any agent, e.g. in 45 rininutes tests, methane yields were $0.5-0.7 \%$ of solvent when using the agents compared to $0.5 \%$ with no agent, and approximately $0.4-0.5$ as great in all of the 15 minute tests. However, appreciably more methane was formed in the DMDS tests, with the increment of methane formation averaging $87 \%$ of the theoretical formation of methane from the decomposition of the DMDS, very close to apparent reaction, $92 \%$, of the agent based on the retained sulfur contents.

Light Liquid Formation - GC simulated distillation of the product liquid from a test with TNPS showed a very considerable enhancement of peaks in nominal $225-250^{\circ} \mathrm{F}$ boiling range, particularly three peaks, corresponding to the expected range for $\mathrm{C}_{9}$ isomers. The total of the enhanced peaks corresponded to $76 \%$ of the quantity to be expected if the TNPS were all converted to $\mathrm{C}_{9}$ isomers, which is slightly below the degree of reaction of the TNPS, $85 \%$, indicated by the sulfur retention in the solvent. 
It is concluded that all three agents would be effective in maintaining sulfide levels, but would leave a small residue of unused material. DMDS would cause additional methane yieid, about 0.5 times the amount of sulfur added. TNPS would produce additional naphtha boiling range product, about 1.7 times the amount of sulfur added.

\section{IMPACT OF $\mathrm{CO}_{2}$ UPON LIQUEFACTION}

Two microautoclave tests were done using $10 \% \mathrm{CO}_{2}$ in hydrogen as the vapor phase environment rather than $100 \%$ hydrogen used in most tests. The tests were done with the HRI 5713 Shipment of Black Thunder coal, at $800^{\circ} \mathrm{F}$ and 2000 psig, for 30 minutes, with HRI 5198 Coal liquefaction distillate as solvent and 1 gram of Presulfided Shell S-317 Catalyst per gram of coal. The following results were obtained, compared to the recent test with $100 \%$ hydrogen atmosphere:

$\mathrm{CO}_{2}$ in Vapor, $\mathrm{V} \%$

Solvent/Coal, Gms/Gm

Coal Conversion, W\%

Resid. Yield, W\% of Conv. Coal

$\mathrm{H}_{2} \mathrm{O}$ Resovery, W\% of Conv. Coal
0.0

4.0

85.1

31.9
0.0

$4.0^{*}$

86.6

22.3
10.8

2.0

90.9

21.7

26
10.8

1.0

89.9

21.6

* Coal sample contained $6.4 \%$ water.

These results indicate no deleterious impact of the $\mathrm{CO}_{2}$ upon conversion, or formation of residual oil, and a possible improvement in performance in these respects. The apparent water formation was considerably higher than can be ascribed to the derivation from coal alone. CO formation in the second test corresponded to only $1 \%$ of the coal reacted, which would discount the possibility of the water gas shift reaction of $\mathrm{H}_{2}$ and $\mathrm{CO}_{2}$, alone, accounting for the additional water formation. However, the light gas formation for this test, $5.4 \mathrm{~W} \%$ of coal, was 2-3 times the amount expected on the basis of other tests, with no $\mathrm{CO}_{2}$. indicating the possibility of water gas shift-hydrocarbon synthesis reaction sequence. 
TASKK 3 - BENCH SCALE STUDIES

\section{RUN CC-12 (227-70) CATALYST REJUVENATION}

\section{Objectives}

The objectives for this run was to evaluate a rejuvenated catalyst (acid wash and carbon removal) that had been recovered after earlier CTSL bench unit operations on Elack Thunder Mine (Wyoming) coal.

The rejuvenated catalyst had residual oil conversion activity, hydrogenation and denitrogenation activity essentially that of fresh catalyst and markedly greater than that of catalyst aged in CTSL operations. There were slightly lower yields of distillate product with the rejuvenated catalyst because of lower coal conversion and higher carbon oxides yields, factors which might not be associated with the catalyst performance. The rejuvenated catalyst was of much lower physical strength, and very much shortened particle length, than fresh catalyst, and a more durabie initial catalyst might be more appropriate if rejuvenated catalysts are to be used commercially.

\section{Scope of Work}

The recovered Shell S-317 catalyst from earlier CTSL runs was acid washed and then regenerated using diluted air. The rejuvenated catalyst was then evaluated in Run CC-12 at a single set of operating conditions to evaluate the deactivation of the rejuvenated catalyst with a comparison with the results of operations with Fresh Shell S-317 catalyst.

\section{Coal}

Black Thunder Mine (Wyoming) sub-bituminous coal (HRI 5713) was used as the feed stock. The coal analyses of the feed are given in Table 1 along with earlie: analyses of this coal.

\section{Catalyst}

The catalyst rejuvenated for use in Run CC-12 had been recovered after Runs CC-4 and CC-7, both of which had been operated with Black Thunder Mine coal and had re-used catalysts recovered after Runs CC-1, CC-2 and CC-5. In these previous operations, the blended catalyst for rejuvenation had processed $1120 \mathrm{lbs}$ coal//b fresh catalyst. Table 2 includes the analysis of the recovered catalyst to rejuvenation, as well as the acid-washed catalyst and the final rejuvenated catalyst used in Run CC-12.

The acid washing phase of the rejuvenation procedure was an agitated batch operation for 30 minutes at $150^{\circ} \mathrm{F}$ using 5 weights of $3.5 \mathrm{~W} \%$ sulfuric acid solution per weight of catalyst. The regeneration of the acid washed catalyst was carried out in two fixed beds in series for the first for 4 hours at $750^{\circ} \mathrm{F}$, with gas containing $2.5 \%$ oxygen, then increasing the temperature to $800^{\circ} \mathrm{F}$ for four hours, and then 
progressively increasing the oxvgen content to $5 \%, 7.5 \%$, and $21 \%$ over a six hour period. The orygen fed with the most dilute gas corresponded to about $100 \%$ excess above the amount required for the combustion of the available carbon.

The metals accountability of this sequence of operations is summarized by Table 3 . Of the contaminants, over $95 \%$ of the calcium, $95 \%$ of the sodium and $60 \%$ of the iron was removed in the acid washing step. There were some losses the promoting metals, about $20 \%$ of the molybdenum, and $60 \%$ of the nickel was removed by the acid-washing. Apparently some of the catalyst support dissolved as well, with aluminum found in the acid washing liquor corresponding to about $5 \%$ of the $\mathrm{Al}_{2} \mathrm{O}_{3}$ content of original recovered catalyst.

The rejuvenated catalyst had a crush strength considerably lower than that of fresh catalyst, $1.23 \mathrm{lb} / \mathrm{mm}$ against $1.94 \mathrm{lb} / \mathrm{mm}$. Also, the rejuvenated extrudates were only half as long, on the average, than fresh extrudates, $1.9 \mathrm{~mm}$ against $4.2 \mathrm{~mm}$, although the extrudate diameters were essentially the same. There were a very large number of very short particles, less than $1 \mathrm{~m}$, in rejuvenated catalyst. This factor caused several false starts for Run CC-12, even before coal feed was started, when the smaller particles became enmeshed in the catalyst support. Successful operation was achieved after the shorter particles were removed by screening. While the recovery of catalyst from the first stage reactor after Run CC-12, $89 \mathrm{~V} \%$, was in the range of values of recovery after operations with fresh catalyst, the recovery of catalyst from the second stage after Run CC- 12 was relatively low, $63 \%$, perhaps a consequence of the low crush strength.

\section{Run Plan}

The run plan is given in Table 4. The run duration was 12 days. The liquefaction conditions were kept constant during this period. The coal space velocity was 45 Ib dry coal/hour/ft3 of catalyst (per stage). The first stage liquefaction temperature was $750^{\circ} \mathrm{F}$ and the second stage temperature ' was $800^{\circ} \mathrm{F}$. The operating conditions were the same as those used in the first operations of Run CC-1. The net liquid products were: 1) separator overhead $(\mathrm{SOH})$ the condensate after cooling to ambient temperature the vapor from the $610^{\circ} \mathrm{F}$ hot separator at the outlet of the second stage; 2) atmospheric overhead $(\mathrm{ASOH})$ from distillation at $525^{\circ} \mathrm{F}$ of the slurry from the hot separator; 3 ) and pressure filter liquid (PFL), in excess of the recycle to slurry the feed coal, obtained by batch filtration of the slurry from the atmospheric still. The solids from the filtration (PFS) were also a net product of the operation. The in-line hydrotreater for the hot separator vapors was not in service for this run.

$\mathrm{H}_{2} \mathrm{~S}$, corresponding to $2 \mathrm{~W} \%$ of the coal, was fed continuously during the run to provide a sulfiding atmosphere.

\section{Performance and Results}

The liquefaction performance of Run CC-12 is summarized in Table 5, which gives the detailed product distribution. Figures 1, 2, and 3 summarize the day-to-day coal conversions, yield of total $\mathrm{C}_{4}-975^{\circ} \mathrm{F}$ distillate product, and yield of $975^{\circ} \mathrm{F}^{+}$residual oil, respectively, and include a comparison with the results of Run CC-1 with fresh catalyst using the same operating conditions. 
Coal conversion in Run C.C-12 averaged $84.7 \%$ of maf coal when the unit had equilibrated after the start-up interval. There was an uncertain downward tend in conversion, of about $1 \%$, as the run progressed. This conversion, for a relatively low-severity operation, was about $1.5 \%$ lower than had been obtained with fresh catalyst during Run CC-1. To assign these differences in catalyst performance is uncertain, since in other operations coal conversion, while improved by the presence of catalyst, has shown virtually no change as the catalyst de activated as indicated by other performance parameters, viz. residual oil formation, hydrogenation, and denitrogenation, and rejuvenated catalyst in Run CC-12 was clearly of high activity in these regards, see below. It is possible these differen ses are due to differences in the coal shipments, with the CC-12 feed containing about $0.5 \%$ more ash, and $0.4 \%$ less hydrogen than in the CC- 1 feed, see Table $\%$.

The yield of $\mathrm{C}_{4}-975^{\circ} \mathrm{F}$ distillate product In Run CC-12 averaged $59.0 \%$ of maf coal, with a downward trend of about $2 \%$ over the course of the run, Figure 2 . The trend is about the same as obtained in runs with fresh catalyst. However, this yield in Run CC-12 was about $3 \%$ lower than obtained with fresh catalyst in Run CC-1. This difference is discussed more fully below in a comparison with the Run CC-1 results.

The yield of $975^{\circ} \mathrm{F}^{+}$residual oil averaged $2.8 \mathrm{~W} \%$ of dry coal during Run CC-12, with a definite upward trend of about $2 \%$ over the course of the run, Figure 3 . The residual oil yield in Run CC-12 was virtually the same as had been obtained with fresh catalyst in Run CC-1 at the same operating conditions, and the trend with increasing catalyst age in Run CC- 12 was close to that obtained with fresh catalyst.

\section{Comparison with Fresh Catalyst Performance}

Table 6 compares the product distribution during Run CC-12 with those with fresh catalyst during Run CC-1. This table includes data from the later portions of Run $\mathrm{CC}-1$, which were a higher severity operation with $25^{\circ} \mathrm{F}$ higher second stage temperature with a portion of the solvent recycle being atmospireric still bottoms slurry which included some unconverted coal. Table 7 gives hydrogen contents, nitrogen contents, sulfur contents, and solvent fractionation results for the producis of the two runs.

\section{Product Distribution}

Referring to Table 6 , in addition to the differences in coal conversion ( $1.8 \%$ lower in Run CC-12), $\mathrm{C}_{4}-9 \overline{7}^{\circ} \mathrm{F}$ distillates yields (3.2\% lower), and residual oil yields (within $0.1 \%$ ) noted above the principal difference in the yields of the two runs was $1.4 \mathrm{~W} \%$ higher carbon oxides yield in Run CC-12, and $0.8 \mathrm{~W} \%$ higher $\mathrm{C}_{1}-\mathrm{C}_{3}$ gas yield. If the yields of the two runs were normalized to a common yield of carbon oxides and water then the yield of $\mathrm{C}_{4}-975^{\circ} \mathrm{F}$ distillate would then be about $1.5 \mathrm{~W} \%$ different for the two runs, the difference in coal conversions.

The trend in residual oil yield in Run CC-12, for the six day interval between the sixth and twelfth day, corresponded to that of nine day interval between the tenth and nineteenth day of Run CC-1. Figure 4 summarizes another aspect of the catalyst performance with respect residuai oil kinetics of the two catalysts, plotting the concentration of residual oil in product slurry from the system against time of operations (catalyst age). In this figure, the trends with time are virtually identical during the two runs. Actually, in the first operations of the two runs, at common operating conditions, in terms of the residual concentration required for the observed 
kinetic performance there was a lower concentration during Run $\mathrm{CC}-12$ than in Run CC-1. This difference indicates better kinetic performance of the rejuvenated catalyst than for the fresh catalyst.

\section{Product Properties}

Hydrogen contents, in the Table 7 analyses of the products, fo: the first operations of two runs, were in same range $+/-0.5 \%$. In the final operations of Run CC- 12 the hydrogen contents average $0.2 \%$ higher than during the first operations of that run, perhaps not a statistically significant difference, but a considerable contrast to the results with the fresh catalyst where hydrogen contents decreased by up to $0.8 \%$ between the tenth and nineteenth days. The hydrogen contents of the first operations of Run CC- 12 averaged $0.6 \%$ higher than those of the final operations of Run CC-1. The hydrogen contents may have begun to be equilibrium limited at the higher operating temperatures of Run CC-1.

Nitrogen contents in the first operations of Run CC-12 were one-fourth to one-third of those in the final operations of Run CC-1, and generally lower than had been obtained in the first operations of Run CC- 1 . The nitrogen analyses during Run CC-12 did not demonstrate the stability exhibited by the hydrogen analyses, although the rate of deactivation in this respect may also have been more moderate than shown in Run CC-1.

Sulfur contents for the products fur both runs were in the minimum range that could be determine accurately with the analyzer that was in use.

The cyclohexane insolubles content of the $975^{\circ} \mathrm{F}^{+}$products throughout Run $\mathrm{CC}-12$ remained at the very low levels that were obtained in first operations of both runs. This stability was in contrast to the pattern of Run CC-1 where there was a 6-7 fold increase in this content between the sixth and nineteenth days.

These analyses show that the rejuvenation effort returned the catalyst kinetic performance to equivalent to that of fresh catalyst. The greater stability of the Run CC- 12 results may have been partly due to inclusion of $2 \% \mathrm{H}_{2} \mathrm{~S}$ with the feed to maintain sulfiding levels (which was not done during Run CC-1). However, in Run CC-11, using fresh catalyst with continuous $\mathrm{H}_{2} \mathrm{~S}$ addition and Biack Thunder Coal, hydrogen contents declined progressively through the run and averaged $0.3 \mathrm{~W} \%$ lower in the thirteenth day than in the fifth day, in contrast to the stable or increasing hydrogen contents in Run CC-12. 
TABLE 1

ANALYSES OF FEED COAL FOR RUN CC-12

Coal

Black Thunder Mine
(Wyoming)

HRI No.

5713

5630

Feed for Run

CC-12

CC-1

Moisture (As Fed)

5.23

8.92

W\% Dry Basis

Carbon

Hydrogen

Sulfur

68.20

4.19

67.70

0.54

4.54

Nitrogen

0.87

(7.72)

Sulfur in Ash

(5.62)

Ash $\left(\mathrm{SO}_{3}\right.$-free)

6.73

Oxygen (by difference)

19.47

0.48

1.05

$(7.15)$

(6.35)

6.01

20.18

Ash Analysis (Ignited, W\% Ash)

(W\% lgnited)

Silica, $\mathrm{SiO}_{2}$

Alumina, $\mathrm{Al}_{2} \mathrm{O}_{3}$

36.16

Titania, $\mathrm{TiO}_{2}$

17.54

Ferric Oxide, $\mathrm{Fe}_{2} \mathrm{O}_{3}$

1.27

Lime, $\mathrm{CaO}$

5.01

Magnesia, MgO

19.69

Potassium Oxide, $\mathrm{K}_{2} \mathrm{O}$

3.99

Sodium Oxicie, $\mathrm{NaO}$

0.43

0.39

Sulfur Trioxide, $\mathrm{SO}_{3}$

12.93

Phosphorous Pentoxide, P205 0.89

Strontium Oxide, SrO

0.95

Barium Oxide, $\mathrm{BaO}$

0.64

Manganese Oxide, Mn304

0.11

Undetermined

0.00

Microautoclave Results*

Thermal Coal Conversion

Thermal $975^{\circ} \mathrm{F}^{+}$Conversion

80.3

45.4

89.8

Catalytic Coal Conversion

Catalytic $975^{\circ} \mathrm{F}^{+}$Conversion

66.4

76.6

44.3

87.9

72.9

- $\quad 800^{\circ} \mathrm{F}, 30$ minutes, 2000 psig $\mathrm{H}_{2}$

4/1 (1) Solvent/Coal/(Shell S-317 Catalyst)

Solvent - Wilsonville Coal Liquefaction Distillate 


\section{TABLE?}

\section{Preparation of Rejuvenated Catalyst for Run CC-12}

Analyses of Catalysts

Catalyst

\begin{tabular}{|c|c|c|c|}
\hline $\begin{array}{l}\text { Fresh } \\
\text { S-317 }\end{array}$ & $\begin{array}{l}\text { Recovered } \\
\text { CC-4, CC-7 }\end{array}$ & $\begin{array}{c}\text { Acid } \\
\text { Washed }\end{array}$ & $\begin{array}{c}\text { Rejuvenated } \\
\text { to CC-12 }\end{array}$ \\
\hline
\end{tabular}

Chemical Analysis, W\%

Molybdenum

Nickel

Carbon

Hydrogen

Nitrogen

Sulfur

Iron

Calcium

Titanium

Ignition Weight Loss, W\%

Physical Properties

Bulk Density, Gms/cc

Particle Density, Gms/cc

Pore Volume

cc/gram

cc/cc particle

Surface Area

Sq. M./gram

Sq. M./cc particle

Crush Strength, Lb/mm

Dimensions

Average Dia., mm Length

Average, $\mathrm{mm}$

$\mathrm{N} \%<1 \mathrm{~mm}$
11.4

2.2

7.8

1.69

17.27

0.66

0.10

4.95

0.48

0.57

0.04

22.3

7.1

9.8

1.34

0.73

18.71

0.79

0.19

0.70

5.56

0.00

1.10

0.22

0.02

0.40

0.05

6.86

0.588

0.941

1.398

1.310

0.649

0.697

0.656

0.249

0.348

0.290

0.380

0.592

0.569

267

251

122

129

169

197

189

1.94

1.78

1.48

1.23

1.0

4.2
0

0.99 


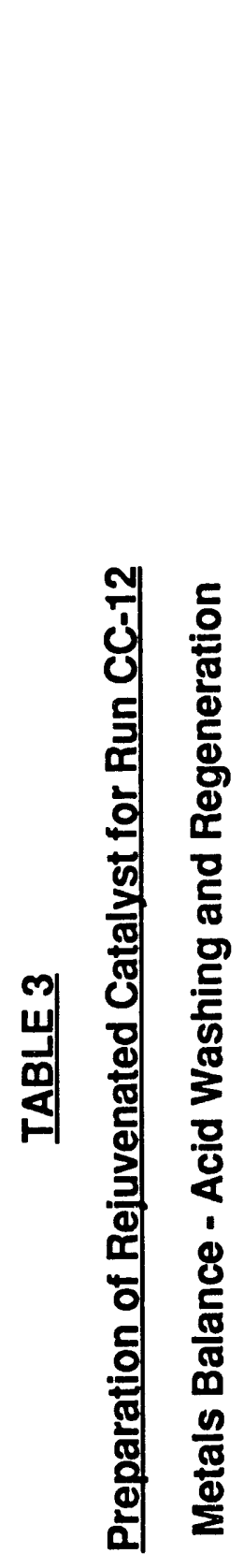

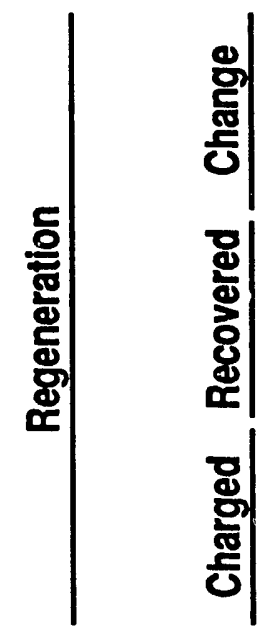

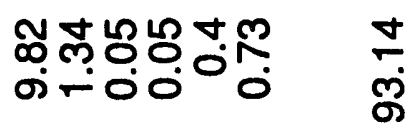

ตํํำ กั0000\%

잏|

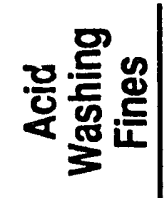

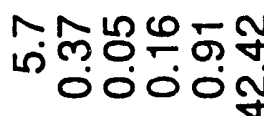

仓़

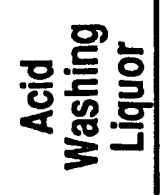

융푱్ㅠ 00000

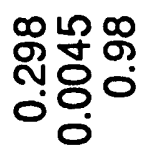

일

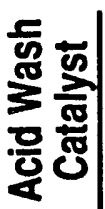

ㅃํํำกำ

N0000\%

동

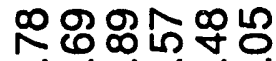

Oกm-mmN

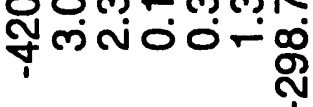

ष प

సิำ0ั0

-

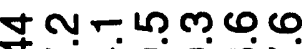

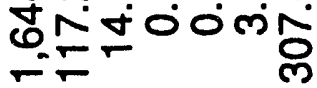

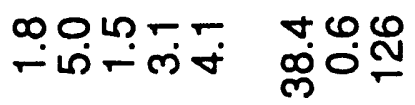

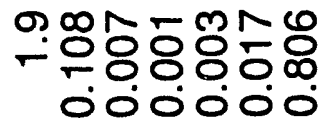

ஜ్య

オเ ما

๙

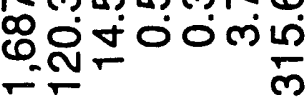

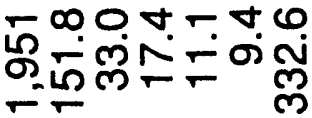

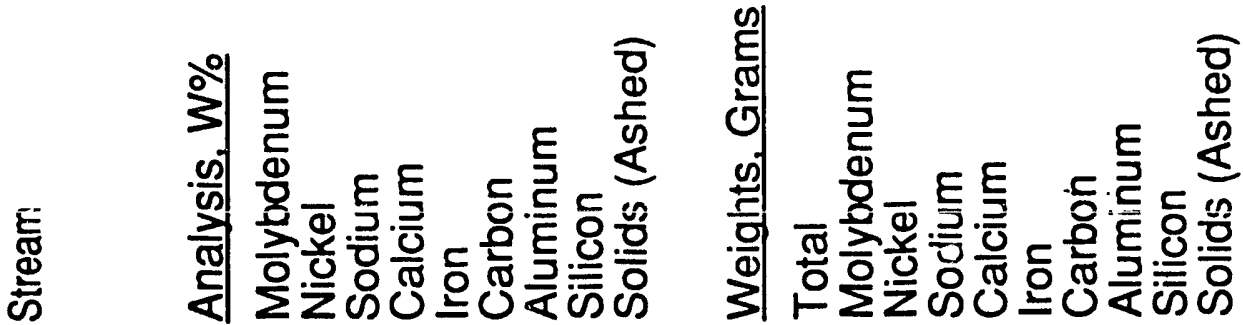




\section{TABLE 4}

\section{RUN CC-12 - RUN PLAN}

Catalyst: Rejuvenated Shell S-317

Period (Days)

Nominal Conditions

Unit Pressure

Coal Feed, lb/hr/ $/ \mathrm{ft}^{3}$ (Catalyst)

Filter Liquid Recycled, W\% Dry Coal

Hydrogen Sulfide Feed, W\% Dry Coal

Atmospheric Still Reboiler Temp., ' $F$
$1 \mathrm{~A}$ to $13 \mathrm{~A}$

2,500

45

116

2
525

\section{Reactor Temperature. ${ }^{\circ} \mathrm{F}$}

First Stage

Second Stage 


\section{TABLE 5}

\section{Liquefaction Performance Run CC-12}

\section{Black Thunder Mine Coal - Rejuvenated Catalyst}

\begin{tabular}{|c|c|c|c|}
\hline Period (Days) & 5-6 & $8-9$ & 11-12 \\
\hline $\begin{array}{l}\text { Added Catalyst Age, Lb Coal/Lb Catalyst } \\
\text { (Stage) }\end{array}$ & 127 & 207 & 288 \\
\hline $\begin{array}{l}\text { Coal Feed Rate } \\
\text { Lb/hr/ft } \\
\text { Catalyst (Stage) }\end{array}$ & 45.2 & 45.8 & 45.4 \\
\hline \multicolumn{4}{|l|}{ Temperatures. ${ }^{\circ} \mathrm{F}$} \\
\hline $\begin{array}{l}\text { First Stage } \\
\text { Second Stage } \\
\text { Hot Separator } \\
\text { Atmospheric Still }\end{array}$ & $\begin{array}{l}750 \\
800 \\
609 \\
531\end{array}$ & $\begin{array}{l}750 \\
800 \\
609 \\
536\end{array}$ & $\begin{array}{l}750 \\
800 \\
609 \\
536\end{array}$ \\
\hline Pressure, psig & 2,509 & 2,513 & 2,510 \\
\hline $\begin{array}{l}\frac{\text { Recycle, Lb/Lb Coal }}{\text { Filtered Liquid }} \\
\text { Atmospheric Bottoms Slurry }\end{array}$ & $\begin{array}{l}1.16 \\
0.00\end{array}$ & $\begin{array}{l}1.16 \\
0.00\end{array}$ & $\begin{array}{l}1.16 \\
0.00\end{array}$ \\
\hline \multicolumn{4}{|l|}{ Normalized Yields (\% Coal) } \\
\hline $\begin{array}{l}\mathrm{C}_{1}-\mathrm{C}_{3} \\
\mathrm{C}_{4}-390^{\circ} \mathrm{F} \\
390-650^{\circ} \mathrm{F} \\
650-850^{\circ} \mathrm{F} \\
850-975^{\circ} \mathrm{F} \\
975^{\circ} \mathrm{F}^{+} \text {Liquid } \\
\text { Unconverted Coal } \\
\text { Ash }\left(\mathrm{SO}_{3} \text { free) }\right. \\
\mathrm{CO}+\mathrm{CO}_{2} \\
\mathrm{NH}_{3} \\
\mathrm{H}_{2} \mathrm{~S} \\
\mathrm{H}_{2} \mathrm{O} \\
\text { Total }\left(100+\mathrm{H}_{2}\right) \text { Consumption }\end{array}$ & $\begin{array}{r}6.79 \\
17.87 \\
23.51 \\
12.14 \\
2.27 \\
2.19 \\
13.88 \\
6.97 \\
1.88 \\
0.85 \\
0.26 \\
18.57 \\
107.21\end{array}$ & $\begin{array}{r}6.71 \\
16.78 \\
23.82 \\
11.55 \\
2.46 \\
2.94 \\
14.94 \\
6.68 \\
1.94 \\
0.75 \\
0.26 \\
18.44 \\
107.23\end{array}$ & $\begin{array}{r}6.53 \\
15.62 \\
23.78 \\
12.36 \\
2.71 \\
3.74 \\
14.38 \\
6.39 \\
1.66 \\
0.78 \\
0.26 \\
18.94 \\
107.21\end{array}$ \\
\hline \multicolumn{4}{|l|}{ Process Performance (W\% MAF) } \\
\hline $\begin{array}{l}\text { Coal Conversion } \\
\text { Coal Plus Resid Conversion } \\
\mathrm{C}_{4}-975^{\circ} \mathrm{F} \text { Yield } \\
\text { Desulfurization } \\
\text { Denitrogenation }\end{array}$ & $\begin{array}{l}85.0 \\
82.7 \\
60.0 \\
44.6 \\
80.0\end{array}$ & $\begin{array}{l}83.8 \\
80.6 \\
58.4 \\
46.5 \\
70.9\end{array}$ & $\begin{array}{l}84.6 \\
80.6 \\
58.2 \\
44.5 \\
73.8\end{array}$ \\
\hline
\end{tabular}




\section{TABLE 6}

\section{Liquefaction Performance Run CC-12 and Run CC-1}

\section{Rejuvenated and Fresh Shell S-317 Catalyst}

\begin{tabular}{|c|c|c|c|c|c|}
\hline \multirow{3}{*}{$\begin{array}{l}\text { Run } \\
\text { Catalyst } \\
\text { Period (Days) }\end{array}$} & \multicolumn{2}{|c|}{$\mathrm{CC}-12$} & \multicolumn{3}{|c|}{ CC-1 } \\
\hline & \multicolumn{2}{|c|}{ Rejuvenated } & \multicolumn{3}{|c|}{ Fresh } \\
\hline & $5-6$ & $11-12$ & $5-6$ & $9-10$ & 19 \\
\hline $\begin{array}{l}\text { Added Catalyst Age, Lb Coal/Lb Catalyst } \\
\text { (Stage) }\end{array}$ & 127 & 288 & 140 & 256 & 541 \\
\hline $\begin{array}{l}\text { Coal Feed Rate } \\
\text { Lb/hr//tit Catalyst (Stage) }\end{array}$ & 45.2 & 45.4 & 44.6 & 45.4 & 45.4 \\
\hline $\begin{array}{l}\text { Temperatures. }{ }^{\circ} \mathrm{F} \\
\text { First Stage } \\
\text { Second Stage } \\
\text { Hot Separator } \\
\text { Atmospheric Still }\end{array}$ & $\begin{array}{l}750 \\
800 \\
609 \\
531\end{array}$ & $\begin{array}{l}750 \\
800 \\
609 \\
536\end{array}$ & $\begin{array}{l}750 \\
800 \\
640 \\
524\end{array}$ & $\begin{array}{l}750 \\
824 \\
622 \\
295\end{array}$ & $\begin{array}{l}750 \\
824 \\
611 \\
294\end{array}$ \\
\hline Pressure, psig & 2,509 & 2,510 & 2,502 & 2,498 & 2,503 \\
\hline $\begin{array}{l}\frac{\text { Recycle. Lb/Lb Coal }}{\text { Filtered Liquid }} \\
\text { Atmospheric Bottoms Slurry }\end{array}$ & $\begin{array}{l}1.16 \\
0.00\end{array}$ & $\begin{array}{l}1.16 \\
0.00\end{array}$ & $\begin{array}{l}1.23 \\
0.00\end{array}$ & $\begin{array}{l}0.84 \\
0.38\end{array}$ & $\begin{array}{l}0.84 \\
0.38\end{array}$ \\
\hline $\begin{array}{l}\text { Yields. W\% of Dry Coall } \\
\mathrm{C}_{1}-\mathrm{C}_{3} \\
\mathrm{C}_{4}-390^{\circ} \mathrm{F} \\
390-650^{\circ} \mathrm{F} \\
650-850^{\circ} \mathrm{F} \\
850-975^{\circ} \mathrm{F} \\
975^{\circ} \mathrm{F}^{+} \text {Liquid } \\
\text { Unconverted Coal } \\
\text { Ash }\left(\mathrm{SO}_{3} \text { free) }\right. \\
\mathrm{CO}+\mathrm{CO}_{2} \\
\mathrm{NH}_{3} \\
\mathrm{H}_{2} \mathrm{~S} \\
\mathrm{H}_{2} \mathrm{O} \\
\text { Total }\left(100+\mathrm{H}_{2}\right) \text { Consumption }\end{array}$ & $\begin{array}{r}6.79 \\
17.87 \\
23.51 \\
12.14 \\
2.27 \\
2.19 \\
13.88 \\
6.97 \\
1.88 \\
0.85 \\
0.26 \\
18.57 \\
107.21\end{array}$ & $\begin{array}{r}6.53 \\
15.62 \\
23.78 \\
12.36 \\
2.71 \\
3.74 \\
14.38 \\
6.39 \\
1.66 \\
0.78 \\
0.26 \\
18.94 \\
107.21\end{array}$ & $\begin{array}{r}7.59 \\
17.59 \\
27.92 \\
11.82 \\
2.06 \\
2.12 \\
12.42 \\
6.01 \\
0.48 \\
0.92 \\
0.36 \\
18.26 \\
107.55\end{array}$ & $\begin{array}{r}8.19 \\
20.14 \\
29.18 \\
12.12 \\
2.06 \\
2.56 \\
8.12 \\
6.01 \\
0.34 \\
0.97 \\
0.36 \\
17.66 \\
107.74\end{array}$ & $\begin{array}{r}8.88 \\
19.90 \\
27.30 \\
10.57 \\
1.97 \\
4.15 \\
7.71 \\
6.01 \\
0.82 \\
0.97 \\
0.36 \\
18.9 \\
107.56\end{array}$ \\
\hline $\begin{array}{l}\text { Process Performance (W\% MAF) } \\
\text { Coal Conversion } \\
\text { Coal Plus Resid Conversion } \\
\mathrm{C}_{4}-975^{\circ} \mathrm{F} \text { Yield } \\
\text { Desulfurization } \\
\text { Denitrogenation }\end{array}$ & $\begin{array}{l}85.0 \\
82.7 \\
60.0 \\
44.6 \\
80.0\end{array}$ & $\begin{array}{l}84.6 \\
80.6 \\
58.2 \\
44.5 \\
73.8\end{array}$ & $\begin{array}{l}86.8 \\
84.6 \\
63.2 \\
70.0 \\
72.2\end{array}$ & $\begin{array}{l}91.2 \\
88.6 \\
67.4 \\
71.2 \\
75.7\end{array}$ & $\begin{array}{l}91.8 \\
87.4 \\
63.6 \\
71.3 \\
75.7\end{array}$ \\
\hline
\end{tabular}




\section{TABLE 7}

\section{CTSL Operations - Rejuvenated and Fresh Catalysts}

Run

Catalyst

Days of Operation

Temperatures, ${ }^{\circ} \mathrm{F}$

First Stage

Second Stage

Hydrogen Contents, W\%

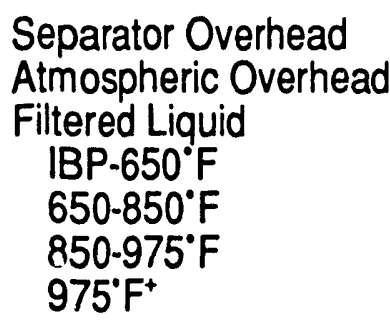

Nitrogen Contents, W\%

Filtered Liquid

IBP-650 $\mathrm{F}$
$650-850^{\circ} \mathrm{F}$
$850-9755^{\circ} \mathrm{F}$
$975^{\circ} \mathrm{F}^{+}$

Sulfur Contents, W\%

Filtered Liquid IBP $650^{\circ} \mathrm{F}$

$650-850^{\circ} \mathrm{F}$

$850-975^{\circ} \mathrm{F}$

$975^{\circ} \mathrm{F}^{+}$

$975^{\circ} \mathrm{F}_{+}$

Cyclohexane Insoluble, W\%

Toluene Insoluble, W\%
CC-12

Rejuvenated

\begin{tabular}{|c|c|c|c|c|c|}
\hline 6 & 9 & 12 & 6 & 10 & 19 \\
\hline $\begin{array}{l}750 \\
800\end{array}$ & $\begin{array}{l}750 \\
800\end{array}$ & $\begin{array}{l}750 \\
800\end{array}$ & $\begin{array}{l}750 \\
800\end{array}$ & $\begin{array}{l}750 \\
824\end{array}$ & $\begin{array}{l}750 \\
824\end{array}$ \\
\hline
\end{tabular}

$\begin{array}{rrrrrr}12.91 & 12.84 & 12.86 & 12.46 & 12.31 & 12.34 \\ 12.57 & 12.35 & 12.47 & 12.28 & 12.89 & 13.06 \\ & & & & & \\ 11.43 & 11.39 & 11.35 & 11.58 & 11.10 & 10.97 \\ 10.52 & 10.90 & 10.94 & 10.94 & 10.34 & 9.85 \\ 9.40 & 9.82 & 9.91 & 9.08 & 8.94 & 8.29 \\ 7.92 & 8.62 & 8.59 & 8.45 & 7.30 & 5.50\end{array}$

0.05

0.06

0.06

0.18

0.13

0.22

$0.03 \quad 0.20$

0.16

0.12

0.11

0.26

0.11

0.28

0.18

0.26

0.30

0.50

$0.25 \quad 0.32$

0.28

0.39

0.51

0.74

$\begin{array}{llllll}0.00 & 0.01 & 0.00 & 0.01 & 0.00 & 0.00 \\ 0.00 & 0.01 & 0.01 & 0.01 & 0.01 & 0.00 \\ 0.00 & 0.00 & 0.00 & 0.02 & 0.00 & 0.01 \\ 0.06 & 0.07 & 0.00 & 0.00 & 0.01 & 0.01\end{array}$

$\begin{array}{rrrrrr}1.83 & 3.83 & 2.09 & 4.35 & 13.87 & 32.55 \\ 0.14 & 0.04 & 0.92 & 0.10 & 0.70 & 6.15\end{array}$


FIGURE 1

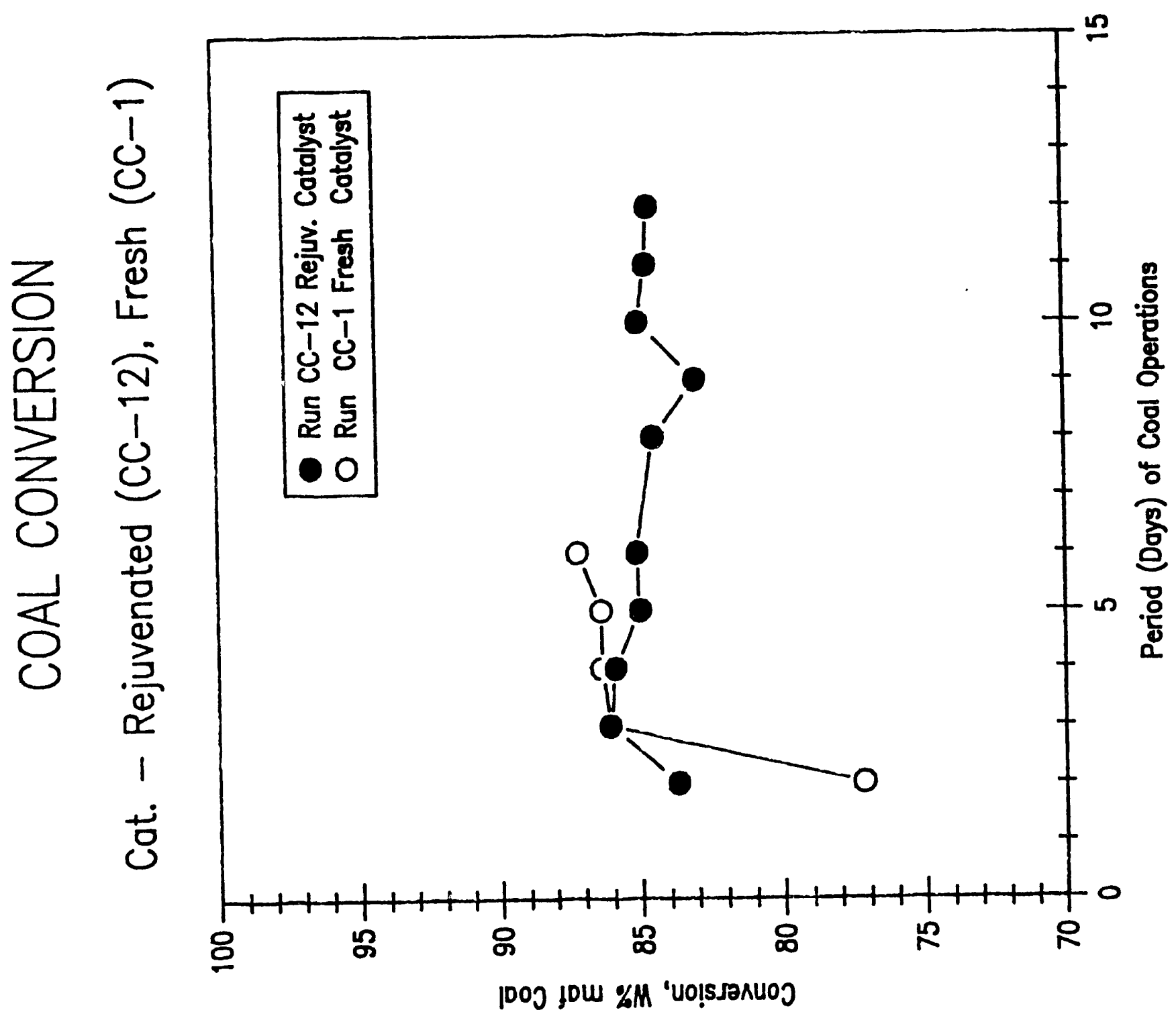


FIGURE 2

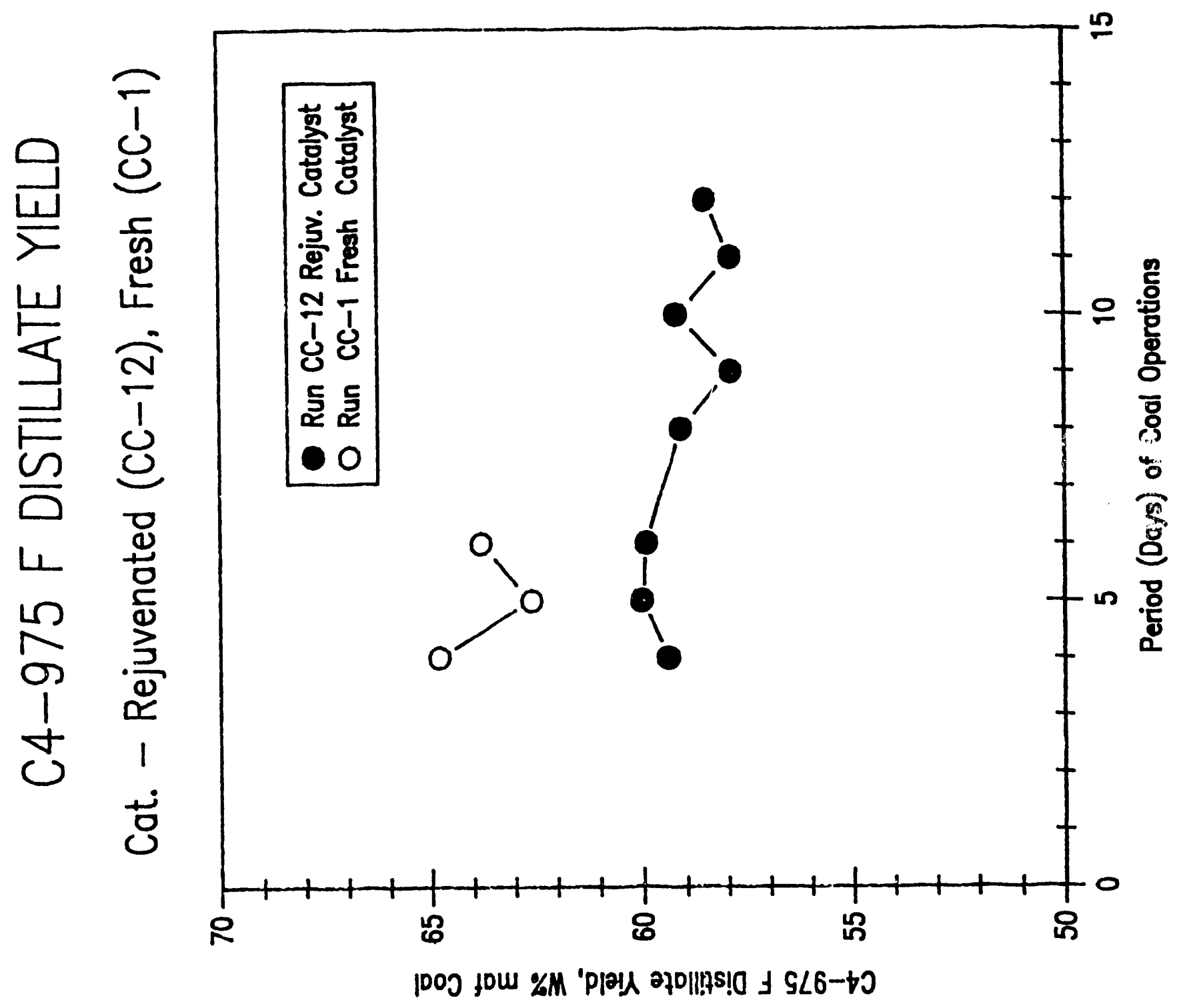


FIGURE 3

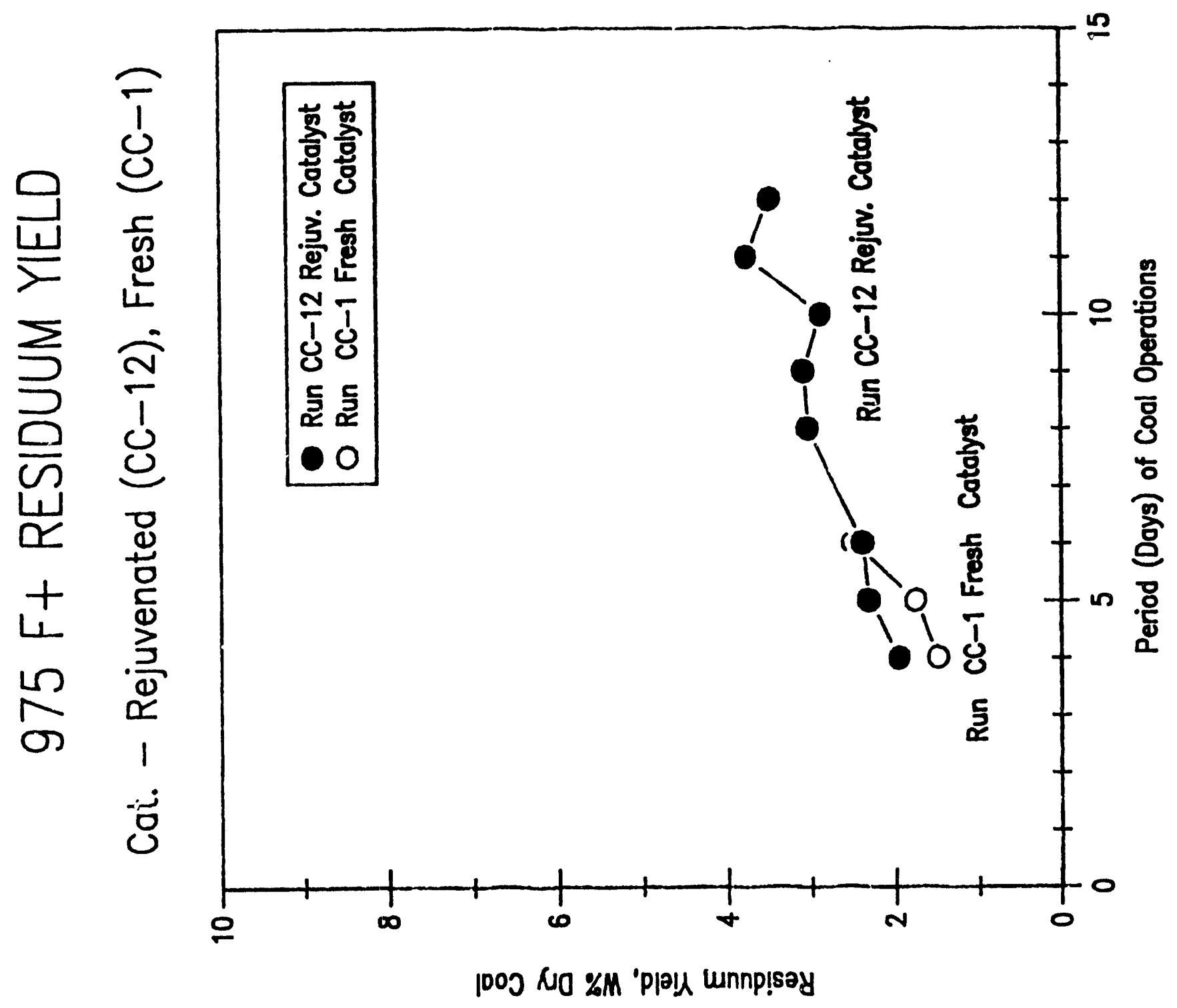


FIGURE 4

RESIDUUM CONCENTRATION IN PRODUCT SLURRY CTSL - Rejuvenated and Fresh Catalyst

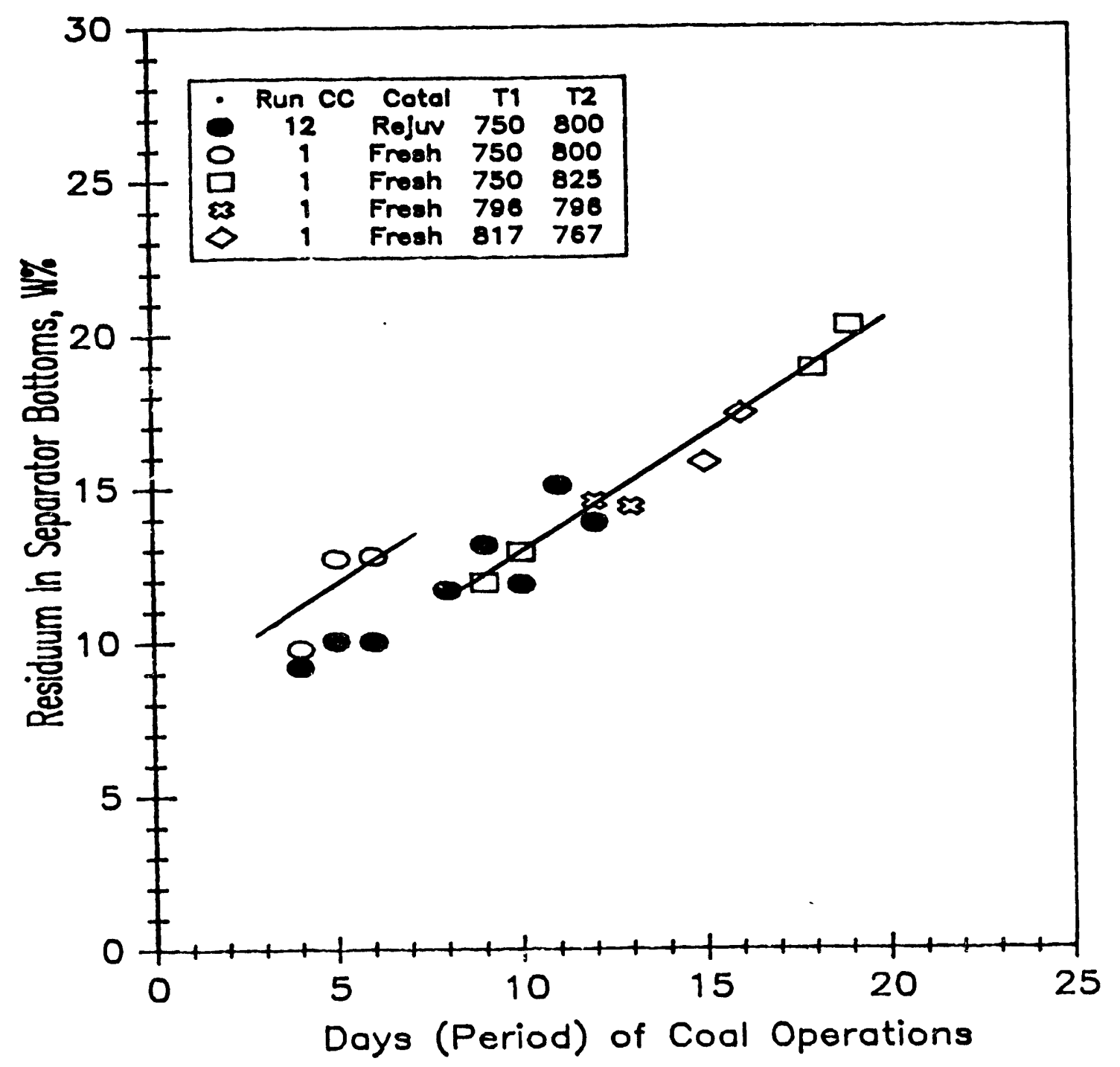




\section{RUN CC-13 (227-71) CO 2 AND LIGHT DISTILLATE SLURRYING}

\section{Objectives}

The objectives of this run were to evaluate $\mathrm{CO}_{2}$ or a vaporizable distillate as feed slurrying agents for coal to the CTSL operation.

\section{Scope of Work}

A feed slurrying agent that would vaporize in the reactor would afford less dilution, than with the usual slurnying agents, of the resulting slurry phase and promote more complete reaction of the coal and heavy primary liquid products to lighter liquids. $\mathrm{CO}_{2}$ has been demonstrated as a feasible slurrying agent for pipeline transport of coal and might be applied for this use in CTSL liquefaction. However, on the small scale of Bench Unit operations it was not possible to maintain $\mathrm{CO}_{2} /$ slurry feed to the unit, and the test program was modified to study the impact of $\mathrm{CO}_{2}$ feed to the process while using the conventional CTSL practice of slurrying the coal with recycled filtered liquid. Also, there was an attempted operation using a light gas oil as slurrying agent in place of the filtered liquid, which was mairitained for 40 hours before problems developed in maintaining feed slurry flow.

\section{Coal and Light Slurry Oil}

The coal feed for Run 227-71 was a recent shipment of Black Thunder Mine coal, HRI 5828. The coal analyses are given in Table 8 . The light slurry oil used in a portion of the run, HRI 5663, was a roal derived distillate obtained from the Wilsonville Coal Liquefaction facility. Its analyses are given in Table 9.

\section{Catalyst}

Shell S-317 NiMo catalyst was used in both stages in 1/32 inch extrudate form. The catalyst was sulfided during the start-up by doping the start-up oil with TNPS (di-tertiary nonyl polysulfide). During coal operations $\mathrm{H}_{2} \mathrm{~S}$, corresponding to $2 \mathrm{~W} \%$ of the coal, was continuously added to maintain the sulfide level of the catalyst.

\section{Run Plan}

The initial intention was to use $\mathrm{CO}_{2}$ as the feed coal slurrying agent directly, by minans of a pressurized, refrigerated slurry preparation system. However, the attempts to prepare a pumpable $\mathrm{CO}_{2}$ /coal slurry on the Bench Unit scale of operations were unsuccessful, principally because high vaporization and vapor-binding of the slurry feed pump. The run plan was then changed to feed $\mathrm{CO}_{2}$ in addition to a feed slurry incorporating a normally liquid material, recycled filtered liquid or light gas oil make-up (which in process application could be recycle from the distillation of the reactor products).

The final run plan is given in Table 10. The run duration was 14 days. After an initial operation of five days, in a normal CTSL configuration with filtered liquid slurrying oil recycle and without $\mathrm{CO}_{2}$ addition, addition of $\mathrm{CO}_{2}$ was started first at a rate of $0.1 \mathrm{lbs} / \mathrm{lt}$ coal, then increasing to $0.25 \mathrm{lbs} / \mathrm{lb}$ coal. Then, on the tenth day, filtered liquid recycle was stopped and replaced by an equal amount of light gas oil make-up. The operation with light gas oil make-up was maintained for 40 hours to the end of the eleventh day, when the feed slurry flow failed because of difficulties 
in keeping the coal in suspension in the light oil. The twelfth day was spent in stabilizing the unit for the final operation with the filtered liquid recycle resumed and the $\mathrm{CO}_{2}$ addition increased of $0.6 \mathrm{ibs} / \mathrm{lb}$ coal to the scheduled end of operations after 14 days.

\section{Performance and Results}

The liquefaction performance during Run $\mathrm{CC}-13$ is summarized in Table 11, which gives the detailed product distribution. Figure 5 summarizes the day-to-day coal conversion. Figures 6 and 7 graphically compare for the four principal operating periods of the run the yield of $\mathrm{C}_{4}-975^{\circ} \mathrm{F}$ distillate product and the yield of $975^{\circ} \mathrm{F}^{+}$ residual oil, respectively.

\section{Coal Conversion}

Coal conversion in Run CC-13 ranged from 90.0 to 94.0 W\%, see Figure 5. The lowest coal conversion was in the first operation of the run, with no $\mathrm{CO}_{2}$ addition. The highest coal conversion was in the operation using light gas oil make-up, and is the highest coal conversion obtained in any CTSL operation with Black Thunder Coal in the current program. The following tabulation summarizes the average coal conversions for the various operations of the run.

\begin{tabular}{|c|c|c|c|}
\hline $\begin{array}{c}\mathrm{CO}_{2} \mathrm{Lb} / \mathrm{Lb} \\
\text { soal }\end{array}$ & $\begin{array}{l}\text { PFL Recycle } \\
\text { Lb/Lb Coal }\end{array}$ & $\begin{array}{l}\text { LGO Mi ke-Up } \\
\text { Lb/Lb Coal }\end{array}$ & $\begin{array}{c}\text { Coal } \\
\text { Conversion } \\
\text { W\% of MAF } \\
\text { Coal } \\
\end{array}$ \\
\hline $\begin{array}{l}0.00 \\
0.08 \\
0.25 \\
0.25 \\
0.56\end{array}$ & $\begin{array}{l}1.18 \\
1.20 \\
1.18 \\
0.00 \\
1.04\end{array}$ & $\begin{array}{l}0.00 \\
0.00 \\
0.00 \\
1.18 \\
0.00\end{array}$ & $\begin{array}{c}90.4 \\
9 \\
92.4 \\
92.5 \\
94.0 \\
93.0\end{array}$ \\
\hline
\end{tabular}

The very high conversion in the operation with light gas oil make-up conforms to the conception of promsting the coal conversion reaction because of less dilution of slurry phase reactants. As an index of this factor, the concentration of mineral matter (ash) in the product slurry from the hot separator (which is an indicator of slurry phase concentrations in the reactors) was about 1.15 times as great with light gas oil make-up as in the previous operation with filtered liquid recycle, while unreacted coal concentration was virtually unchanged. The increase in coal conversions because of the $\mathrm{CO}_{2}$ additions did not have a similar relation to apparent changes in slurry phase compositions. Apparently, the $\mathrm{CO}_{2}$ either had an interaction with the unreacted coal, or improved the liquid/coal contact to promote higher coal conversions.

Actually, the reduction of in the amount of product slurry (in effect the impact upon heavy reactant dilution) was not as great as might be obtained with a more volatile slurrying agent. The increase in hot separator vapor phase condensate by using the light gas oil slurrying agent was about $30 \%$ of the amount of the light gas oil feed. In effect, about $70 \%$ of the light gas oil wound up in the slurry. phase. Presumably, a still lighter slurrying agent would promote higher ccal conversion, although the problems of handling the light oil/coal would be compounded. 
$\mathrm{C}_{4}-975^{\circ} \mathrm{F}$ distillate yield was $60.7 \mathrm{~W} \%$ of MAF coal in the conventional reference operations at the beginning of the run, 3-6 W\% higher in the operations with $\mathrm{CO}_{2}$, and 5 W\% lower in the operations with the light gas oil slurrying agent, see Figure 6. The nominal impact of $\mathrm{CO}_{2}$ addition was greater than the associated $2 \%$ increase in coal conversion, indicating a possible ancillary contribution to the change in $\mathrm{C}_{4}-975^{\circ} \mathrm{F}$ distillate yield. Since there was only a small impact of $\mathrm{CO}_{2}$ addition upon residual oil yield, see below, this Iraves the possibility of some hydrocarbon synthesis (Fischer-Tropsch) reaction to produce liquids. While there was almost certainly additional methane formation with the $\mathrm{CO}_{2}$ addition, see below, there was apparently very little change in $\mathrm{C}_{2}$ and $\mathrm{C}_{3}$ hydrocarbon formation so that the synthesis, of still heavier hydrocarbons seems unlikely. The difference in incremental liquid yield and incremental coal conversion more probably reflects material balance difficulties which were occasioned by the somewhat erratic rate of $\mathrm{CO}_{2}$ addition during these operations.

The $5 \mathrm{~W} \%$ lower $\mathrm{C}_{4}-975^{\circ} \mathrm{F}$ distillate yield while using the light gas oil makeup, despite a $3 \%$ increase in coal conversion, was caused largely by the $5 \mathrm{~W} \%$ higher residual oil yield for that operation. This change was riot because of any kinetic impact of the light gas oil, but rather because there was no residual oil recycle, and an appreciable amount of net slurry product was generated, approximately one pound per pound of coal fed. The ultimate application of light slurry recycle will have to incorporate a portion of residual oil recycle to limit the formation of residual oil, i.e. a lower concentration of the resid reactant gives a lower rate of production of distillate product, even if the rate constant remains the same.

$975^{\circ} \mathrm{F}^{+}$Residual oil yield was $1.3 \mathrm{~W} \%$ of MAF coal in the conventional reference operations at the beginning of the run, about this level or slightly lower in the operation with $\mathrm{CO}_{2}$ addition, and $5 \mathrm{~W} \%$ higher in the operation using the light gas oil slurrying agent, see Figure 7. Figure 8 reflects the apparent kinetics of second residual oil conversion reactions, by comparing the residual oil concentrations in the product (hot separator) slurry for the various operations of Run $\mathrm{CC}-13$, and comparable operations of CC-1, in which no $\mathrm{CO}_{2}$ was added. In general, the residual il concentrations for the operations with $\mathrm{CO} 2$ addition lie below what would be expected for a comparable operation with no $\mathrm{CO}_{2}$ addition. However, the differences are small in the first part of Run CC-13, and the larger difference at the end may largely be due failure to reach an equilibrated condition after the upset at the end of the eleventh day and stabilizing the unit in the twelfth day.

Figure 8 shows, for the operation with the light gas oil slurry agent, a very much lower residual oil concentration, by a factor of 2 , in the product slurry than in the contemporary operations of the run. This nominally indicates enhanced residual oil kinetics in this mode, although more detailed flash calculations at the actual reactor conditions (at $825^{\circ} \mathrm{F}$ against the separator temperature of $600^{\circ} \mathrm{F}$ ) will have to be made to see if the difference in compositions is as great at the reactor conditions.

\section{$\mathrm{CO}_{2}$ Reactions}

It is to be noted in Table 11, that there are apparent rieguive yields of $\mathrm{CO}_{2}$ for all of the operations with $\mathrm{CO}_{2}$ addition, and higher yields of $\mathrm{C}_{1} \mathrm{C}_{3}$ gases, $\mathrm{CO}$, and water than were obtained in the reference operation at the beginning of the run with no $\mathrm{CO}_{2}$ addition. Figure 9 relates the amount of $\mathrm{CO}_{2}$ in the outlet gases to the amount of $\mathrm{CO}_{2}$ added to the operation. Figures $10,1 \%$, and 12 give a similar relation for the 
net yields of $\mathrm{H}_{2} \mathrm{O}, \mathrm{CO}$, and $\mathrm{CH}_{4}$, respectively. Each of these figures contain the least squares relations for the factors correlated, all of which were highly significant, statistically, with confidence levels above $99 \%$.

The correlated values for the proportion of $\mathrm{CO}_{2}$ addition that reacts, and the amounts of additional products were the following:

$$
\underline{\text { Lbs/Lb CO}} 2 \text { Added }
$$

$\mathrm{CO}_{2}$ Reacted

Incremental $\mathrm{H}_{2} \mathrm{O}$ Formed Incremental CO Formed Incremental $\mathrm{CH}_{4}$ Formed

$\mathrm{C}$ in $\mathrm{CO}_{2}$ Reacted

$\mathrm{O}$ in $\mathrm{CO}_{2}$ Reacted

$\mathrm{C}$ in $\mathrm{CO}$ and $\mathrm{CH}_{4}$ Formed

$\mathrm{O}$ in $\mathrm{CO}$ and $\mathrm{H}_{2} \mathrm{O}$ Formed

$\mathrm{H}$ in $\mathrm{CH}_{4}$ and $\mathrm{H}_{2} \mathrm{O}$ Formed
0.583

0.427

0.105

0.143

0.159

0.424

0.152

0.439

0.083

These correlations indicate that $58.3 \%$ of the $\mathrm{CO}_{2}$ was reacted. The elemental balances indicate that $\mathrm{CO}, \mathrm{CH}_{4}$, and $\mathrm{H}_{2} \mathrm{O}$ were the only products that were formed from the $\mathrm{CO}_{2}$.

Considering the other light gas products that might have been formed, the following tabulation compares their average collected yields for the operations with and without $\mathrm{CO}_{2}$ addition:

Yields, W\% of Dry Coal

\begin{tabular}{|c|c|c|}
\hline $\mathrm{No} \mathrm{CO}_{2}$ & $\mathrm{CO}_{2}$ Added & $\begin{array}{c}\text { Confidence } \\
\text { Level, \% }\end{array}$ \\
\hline $\begin{array}{l}2.61 \\
3.23 \\
2.44\end{array}$ & $\begin{array}{l}2.11 \\
3.06 \\
2.26\end{array}$ & $\begin{array}{l}83.7 \\
39.1 \\
57.1\end{array}$ \\
\hline 8.28 & 7.43 & 76.5 \\
\hline
\end{tabular}

The confidence levels noted here are a comparison of the averages with and without $\mathrm{CO}_{2}$ addition. Although in each case the average of the yields with $\mathrm{CO}_{2}$ addition was lower than that without $\mathrm{CO}_{2}$ addition, the scatter of the data was such as to result in relatively low statistical confidence levels. The sum of the $C_{2}, C_{3}$, and $C_{4}$ yields did have a marginally significant correlation against the amount of $\mathrm{CO}_{2}$ fed, $92.3 \%$ confidence level, as summarized by Figure 13 . The correlation indicates $1.8 \mathrm{~W} \%$ of dry coal lower yield of these components when the $\mathrm{CO}_{2}$ addition was $0.6 \mathrm{lbs} / \mathrm{lb}$ dry coal. This relation suggests that $\mathrm{CO}_{2}$ inhibits the formation of light gases during the liquefaction/conversion of the coai, osiensibiy by a chain quenching effect, although the experimental support of such a hypothesis is weak. 


\section{Product Properties}

Table 12 summarizes the hydrogen, nitrogen, and sulfur analyses of the liquid products from Run CC-13. The hydrogen contents of the products for the final operation of the run, while feeding $0.55 \mathrm{lbs} \mathrm{CO}_{2} / \mathrm{lb}$ coal, were $0.18 \%$ to $1.23 \%$ lower than those of the products in the conventional operation at the beginning of the run, with the difference being the greatest for the heavy liquid product fractions. In Run CC-11 the decrease in hydrogen contents over a comparable interval of the run was $0.09 \%$ to $0.44 \%$, so that Run $\mathrm{CC}-13$ operation with $\mathrm{CO}_{2}$ addition displayed a lower hydrogenation effectiveness. This difference might be due to some degree to dilution of the hydrogen because of the added $\mathrm{CO}_{2}$ and its products, but the hydrogen partial pressure was only about 100 psi lower in the final operation of Run CC-13 than in the initial operation, because the system pressure had been raised to $2800 \mathrm{psi}$, from $2500 \mathrm{psi}$, for the final operation.

The change in nitrogen contents of the products in course of Run CC-13 were approximately the same as during Run CC-12.

Cyclohexane insolubles content of the $975^{\circ} \mathrm{F}^{+}$product for the final operations of Run CC-13 were over twice the amount for the final operations of Run CC-11. 


\section{Analyses of Feed Coal for Run CC-13}

Coal

HRI No.

Feed for Run

Moisture (As Fed)

W\%, Dry Basis

Carbon

Hydrogen

Nitrogen

Ash

Sulfur in Ash

Ash ( $\mathrm{SO}_{3}$-free)

Oxygen (by difference)
Black Thunder Mine

(Wyoming)

$5828 \quad 5630$

$\mathrm{CC}-13 \quad \mathrm{CC}-1$

$4.83 \quad 8.92$

$68.01 \quad 67.70$

$4.10 \quad 4.54$

$0.93 \quad 1.05$

(7.64) (7.15)

(5.97)

6.50

19.91

(6.35)

6.01

20.18

36.42

15.67

1.22

6.64

19.83

3.98

0.39

0.76

12.36

0.77

0.83

0.46

0.15

0.52

34.61

16.98

1.30

6.94

21.74

4.40

0.35

0.97

10.74

1.01

0.29

0.37

0.00

0.30

80.3

45.4

89.8

66.4

84.2

63.9

Thermal $975^{\circ} \mathrm{F}^{+}$Conversion

Catalytic Coal Conversion

Catalytic $975^{\circ} \mathrm{F}^{+}$Conversion

** $800^{\circ} \mathrm{F}, 30$ minutes, $2000 \mathrm{psig}_{2}$,

$4 / 1 /(1)$ Solvent/Coal/(Shell S-317 Catalyst)

Solvent - Wilsonville Coal Liquefaction Distillate 


\section{TABLE 9}

Inspection Light Solvent Slurry Oil for Run CC-13

Designation

Gravity, 'API

Distillation Temp.. ${ }^{\circ} \mathrm{F}$

IBP

$10 \mathrm{~V} \%$

$20 \mathrm{~V} \%$

$30 \mathrm{~V} \%$

$40 \mathrm{~V} \%$

$50 \mathrm{~V} \%$

$60 \mathrm{~V} \%$

$70 \mathrm{~V} \%$

$80 \mathrm{~V} \%$

$90 \mathrm{~V} \%$

E.P.

Recovery, V\%

Residue, W\%

W\%@650'F

Carbon, W\%

Hydrogen, W\%

Nitrogen, $W \%$

Sulfur, W\%
HRI 5663

26.0

148

250

323

390

474

520

543

580

615

660

748

100

0.0

79.9

87.71

12.09

0.16

0.02 
TABLE 10

\section{Run CC-13 (227-71) - Operational Summary}

Catalyst - Fresh Shell S-317

Condition

Period (Days)

$\frac{1}{1-5} \frac{2}{6-7} \frac{3}{8-9} \frac{4}{10-11} \frac{5}{12-14}$

Nominal Conditions

Unit Pressure, psig

Coal Feed, Lb/Hr/Ft (Catalyst)

Filtered Liquid Recycle, Lb/Lb/Dry Coal

Hydrogen Sulfide Feed, W\% of Dry Coal

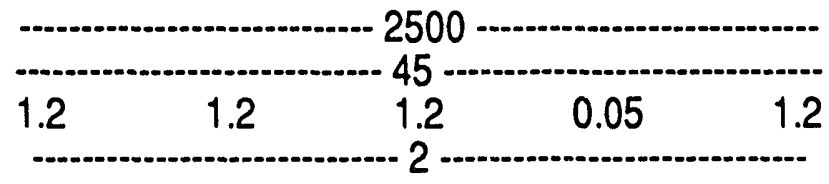

Atmospheric Still Reboiler Temp., $F$

Reactor Temperatures, ${ }^{\circ} \mathrm{F}$

First Stage

Second Stage

$\mathrm{CO}_{2}$ Addition, Lb/Lb Dry Coal

Light Gas Oil Addition, Lb/Lb Dry Coal

$\begin{array}{lllll}0.0 & & & & \\ 0.1 & 0.25 & 0.25 & 0.6 \\ 0.0 & 0.0 & 0.0 & 1.1 & 0.0\end{array}$




\section{TABLE 11}

\section{Liquefaction Performance Run $\mathrm{CC}-13$}

Black Thunder Mine Coal - $\mathrm{CO}_{2}$ Addition and Light Solvent Slurry

CCNDITION

Periods (Days)

$\frac{1}{5} \frac{2}{7} \frac{3}{9} \frac{4}{11} \frac{5}{14}$

Catalyst Age, Lb Dry Coal/Lb

Catalyst) (Stage)

Coal Feed Rate, Lb/Hr/Ft $\mathrm{t}^{3}$ Catalyst (Stage)

$\mathrm{CO}_{2}$ Addition, Lb/Lb Dry Coal

Oil Addition (HRI-5663), Lb/Lb/ Dry Coal

Filtered Liquid Recycle, Lb/Lb Dry Coal

143

44.2

0.0

0.0

1.18

Temperatures, ${ }^{\circ} \mathrm{F}$

First Stage

Second Stage

Hot Separator

Atmospheric Still

Pressure, psig

Normalized Yields (W\% of Dny Coall)

$\mathrm{C}_{1}-\mathrm{C}_{3}$

$\mathrm{C}_{4}-39^{\circ} \mathrm{F}$

390-650 $\mathrm{F}$

$650-850^{\circ} \mathrm{F}$

$850-975^{\circ} \mathrm{F}$

$975^{\circ} \mathrm{F}^{+}$Liquid

Unconverted Coal

Ash ( $\mathrm{SO}_{3}$-free)

Water

$\mathrm{CO}$

$\mathrm{CO}_{2}$

$\mathrm{NH}_{3}$

$\mathrm{H}_{2} \mathrm{~S}$

Total (100 + $\mathrm{H}_{2}$ Consumption) 108.59

Process Performance (W\% MAF)

Coal Conversion

$975^{\circ} \mathrm{F}^{+}$Conversion

$\mathrm{C}_{4}-975^{\circ} \mathrm{F}$ Distillate Yield

Desulfurization

Denitrogenation

752

829

607

534

2,502
90.8

89.4

60.7

63.5

90.7

$\begin{array}{rrrr}201 & 259 & 318 & 401 \\ 44.7 & 44.9 & 44.9 & 43.3 \\ 0.74 & 0.245 & 0.255 & 0.556 \\ 0.0 & 0.0 & 1.18 & 0.0 \\ 1.20 & 1.18 & 0.00 & 1.04\end{array}$

750

827

608

537

2,596

752

752

751

828

599

828

602

829

-.

525

2,652

524

2,595

12.76

21.30

33.68

6.36

1.07

1.15

7.03

10.96

11.69

22.73

11.85

5.66

5.89

5.64

6.50

(21.91)

37.66

(1.30)

0.97

(0.36)

$-18.34$

0.96

0.39

111.51

6.50

37.44

3.62

$-13.71$

0.92

0.44

109.62

16.97

17.62

33.94

7.53

0.53

0.86

6.53

6.50

39.32

7.31

$-26.25$

0.95

0.44

112.26

91.2

92.5

94.0

93.0

91.2

66.8

87.7

55.5

75.7

92.1

67.3

81.0

63.8

75.4

84.9

84.3

Period 7 yields are collected yields, other yields are normalized yields. 
TABLE 12

Analyses of Products - Run CC-13

CTSL Operations - $\mathrm{CO}_{2}$ and Light Distillate Feed

Days of Operation

$\mathrm{CO}_{2}$ Feed, Lbs/Lb Dry Coal

Light Gas Oil Feed, Lbs/Lb Dry Coal

\begin{tabular}{crrr}
5 & \multicolumn{1}{c}{$\frac{9}{0.245}$} & $\frac{11}{0.255}$ & $\frac{14}{0.556}$ \\
0.00 & 0.00 & 1.18 & \\
0.00 & 1.18 & 0.00 & \\
1.18 & 1.04
\end{tabular}

Hydrogen Contents, W\%

Separator Overhead
Atmospheric Overhead
Filtered Liquid
IBP-650 $\mathrm{F}$
$650-850^{\circ} \mathrm{F}$
$850-975{ }^{\circ} \mathrm{F}$
$975^{\circ} \mathrm{F}^{+}$

12.73

12.27

11.31

10.07

Nitrogen Contents, W\%

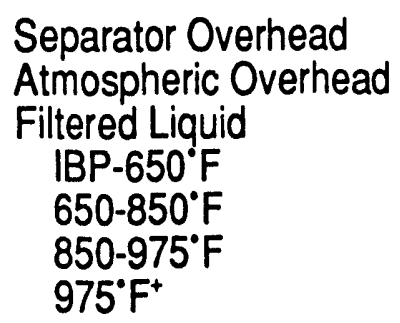

Sulfur Contents, W\%

Separator Overhead

Atmospheric Overhead

Filtered Liquid

IBP- $650^{\circ} \mathrm{F}$

$650-850^{\circ} \mathrm{F}$

$850-975^{\circ} \mathrm{F}$

$975^{\circ} F^{+}$

$\underline{975^{\circ} \mathrm{F}+}$

Cyclohexane Insoluble, W\%

Toluene Insoluble, W\%

Atmospheric Overhead

0.00
0.01

0.01

0.03

0.02

0.03

18.1

1.1
8.50

6.96

0.04

0.07

0.08

0.05

0.23

0.50

12.50

12.12

12.96

12.04

11.02

9.81

7.98

6.38

11.02

10.13

8.26

6.26

12.06

11.90

10.90

9.89

7.73

5.73

0.12

0.11

0.14

0.15

0.14

0.22

0.14

0.13

0.15

0.11

0.34

0.28

0.19

0.47

0.42

0.62

0.68

0.66

0.02

0.02

0.03

0.03

0.00

0.00

0.01

0.03

0.03

0.02

0.04

0.03

0.01

0.02

0.04

0.05

0.06

0.04

27.5

41.3

35.3

3.1

6.2 
FIGURE 5

\section{COAL CONVERSION RUN CC-13 \\ CTSL - With CO2 and Light Distillate}

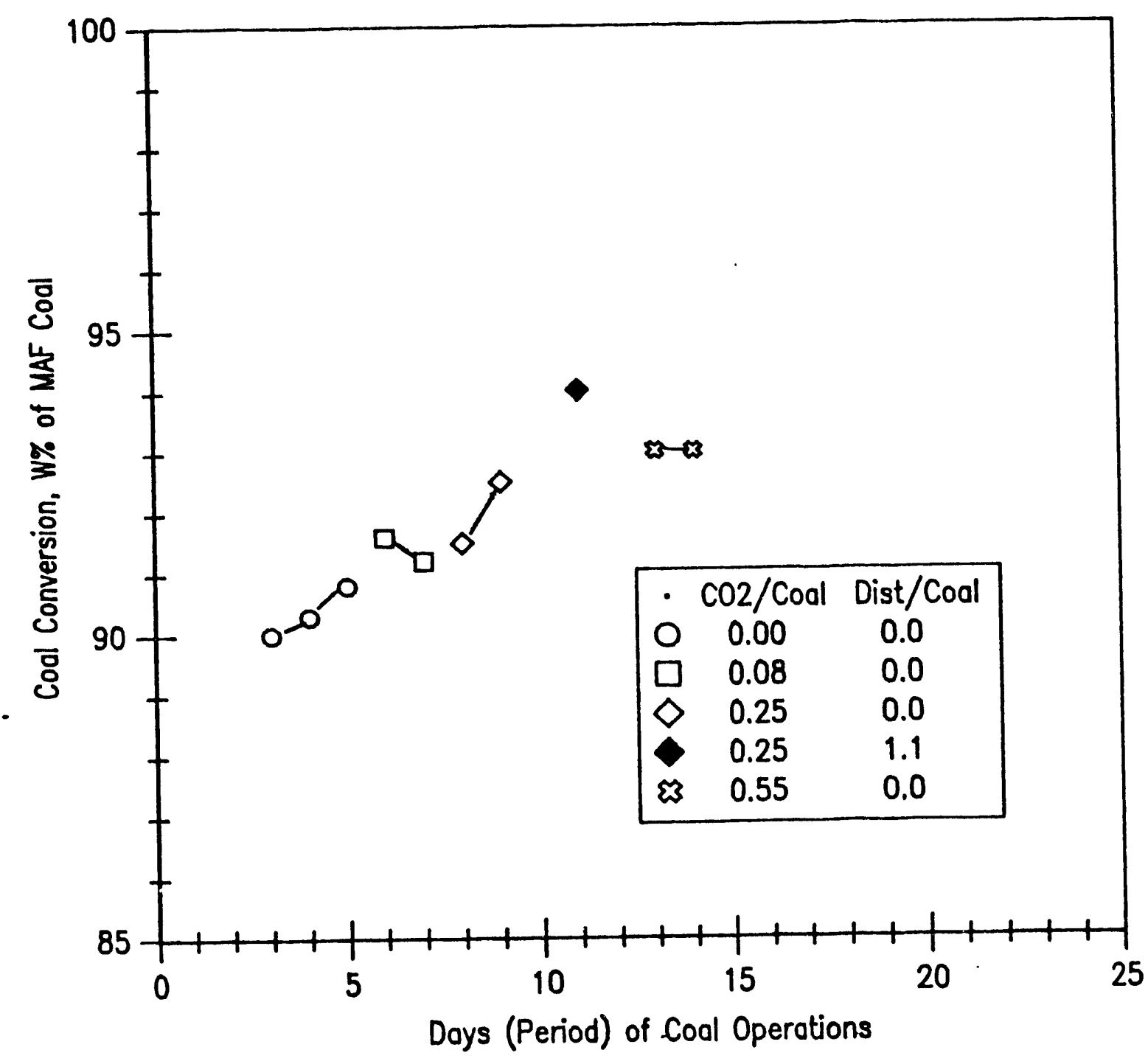


FIGURE 6

\section{C4-975 F LIQUID YIELDS - RUN CC-13 \\ CTSL - With CO2 and Light Distillate}

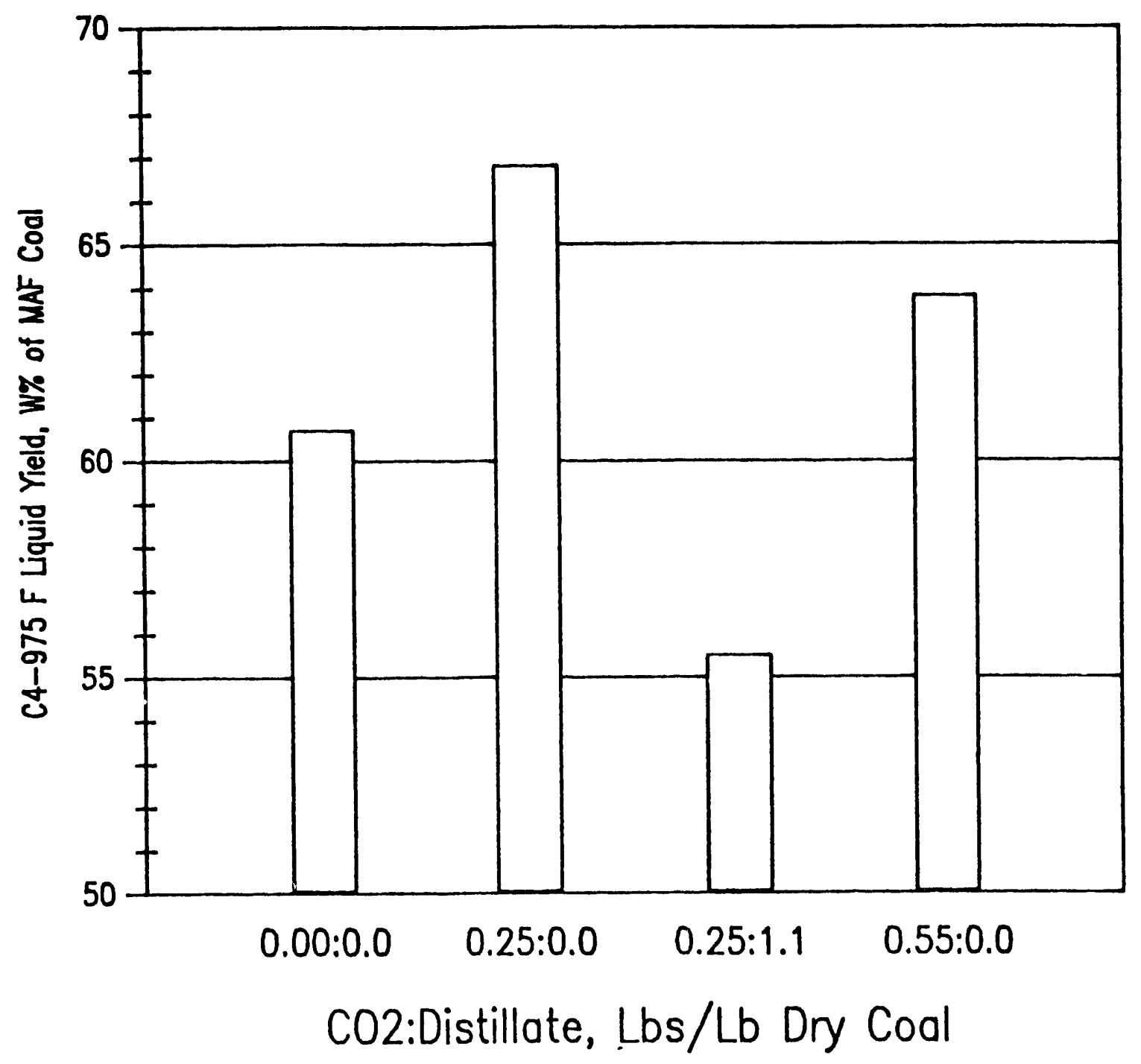


FIGURE 7

Residual Oil Yields - Run CC-13

CTSL - With CO2 and Light Distillate

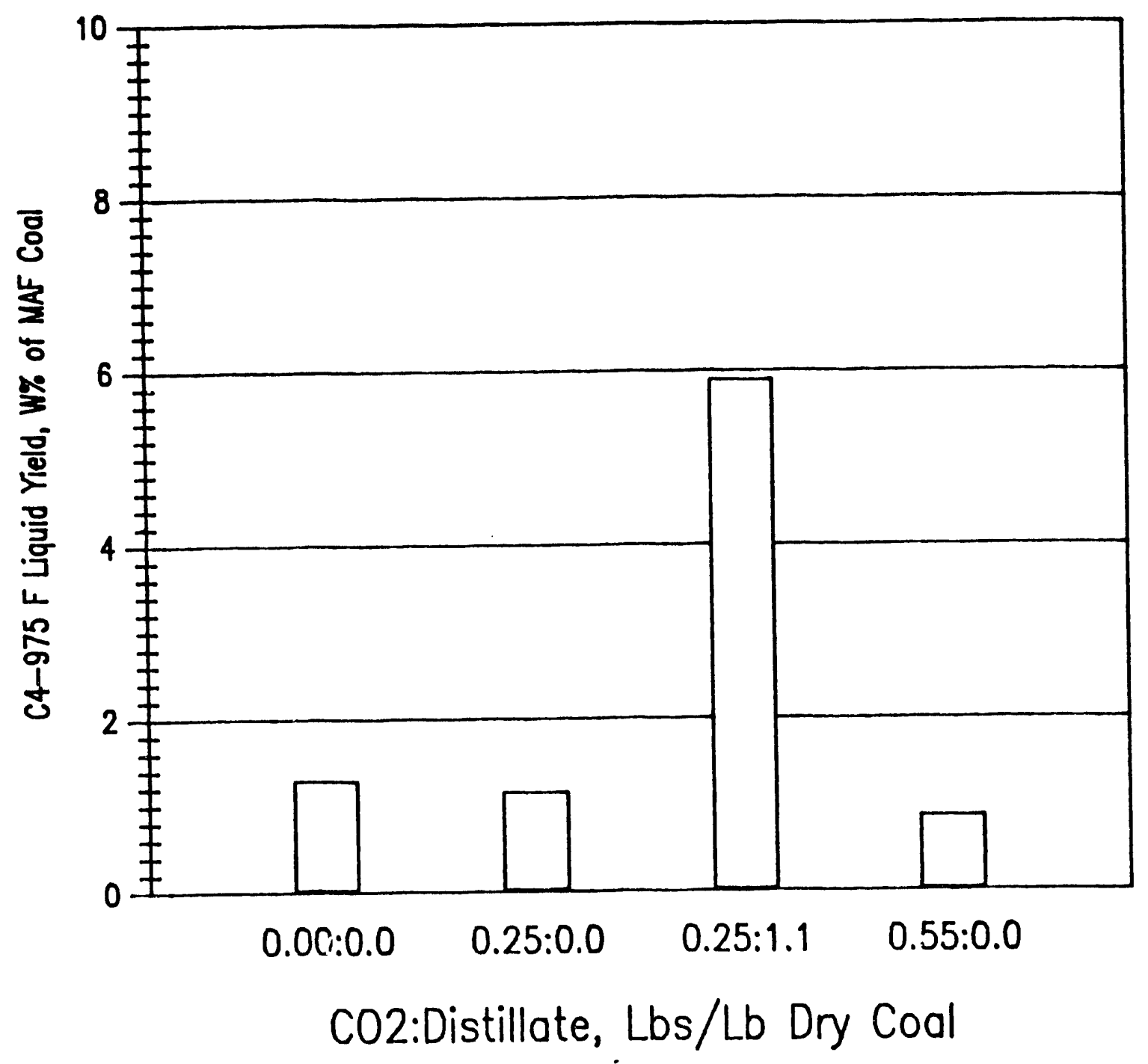


FIGURE 8

\section{RESIDUUM CONCENTRATION IN PRODUCT SLURRY CTSL - With $\mathrm{CO} 2$ and Light Distillate}

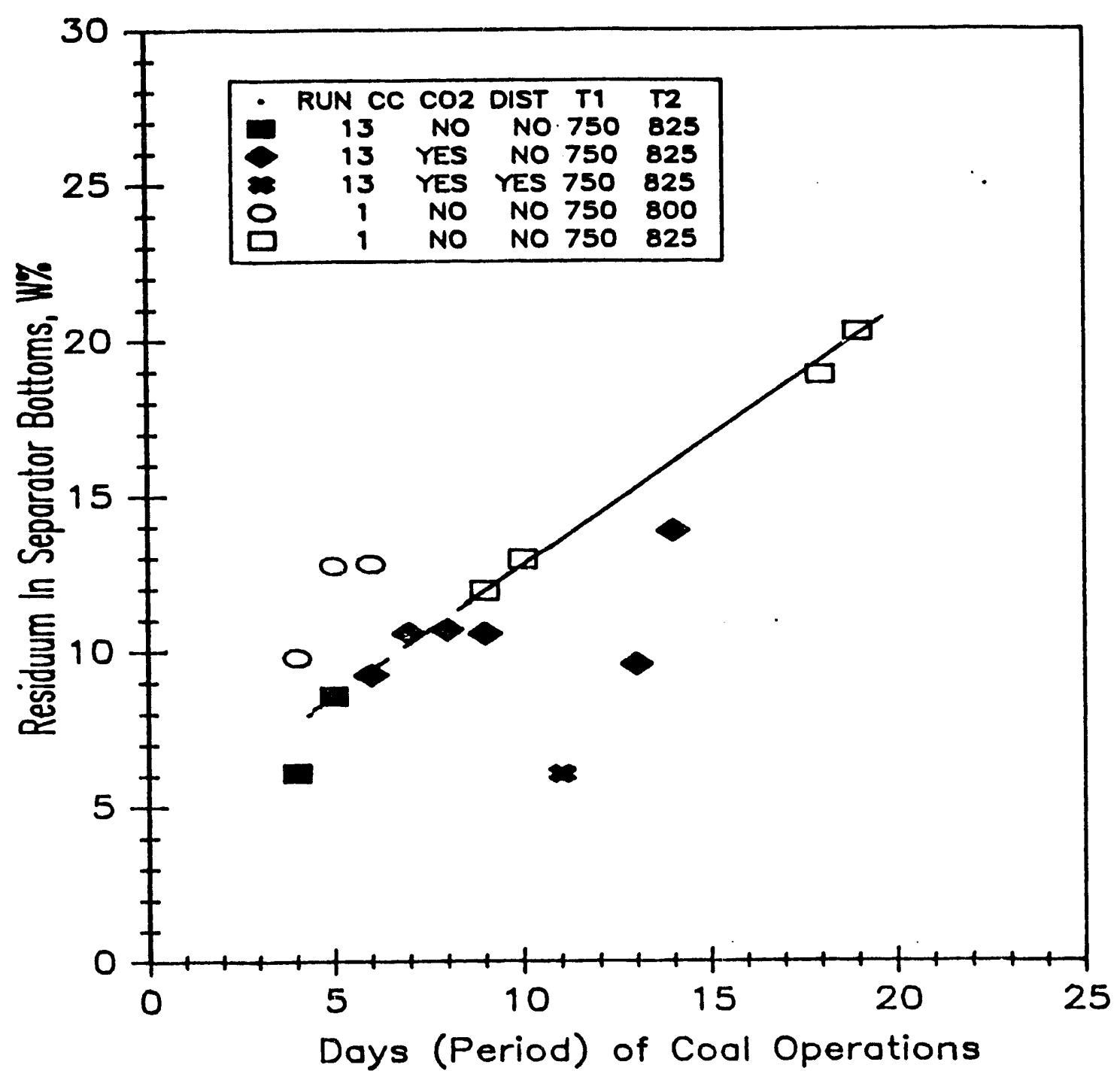


FIGURE 9

\section{C02 OUT VS C02 FED \\ CTSL Run CC-13 - Collected Yields}

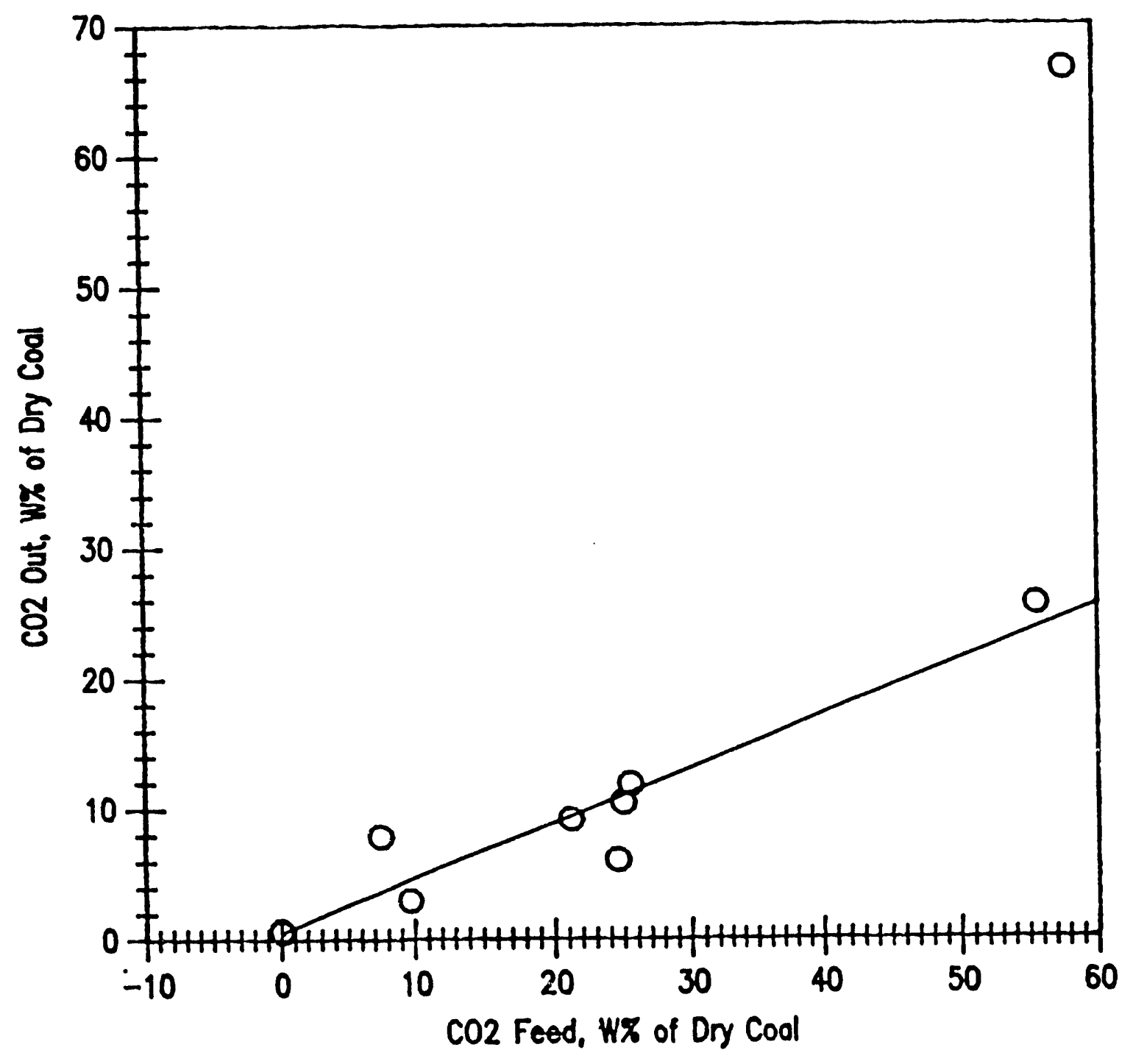


NET H2O FORMATION VS C02 FED CTSL Run CC-13 - Collected Yields

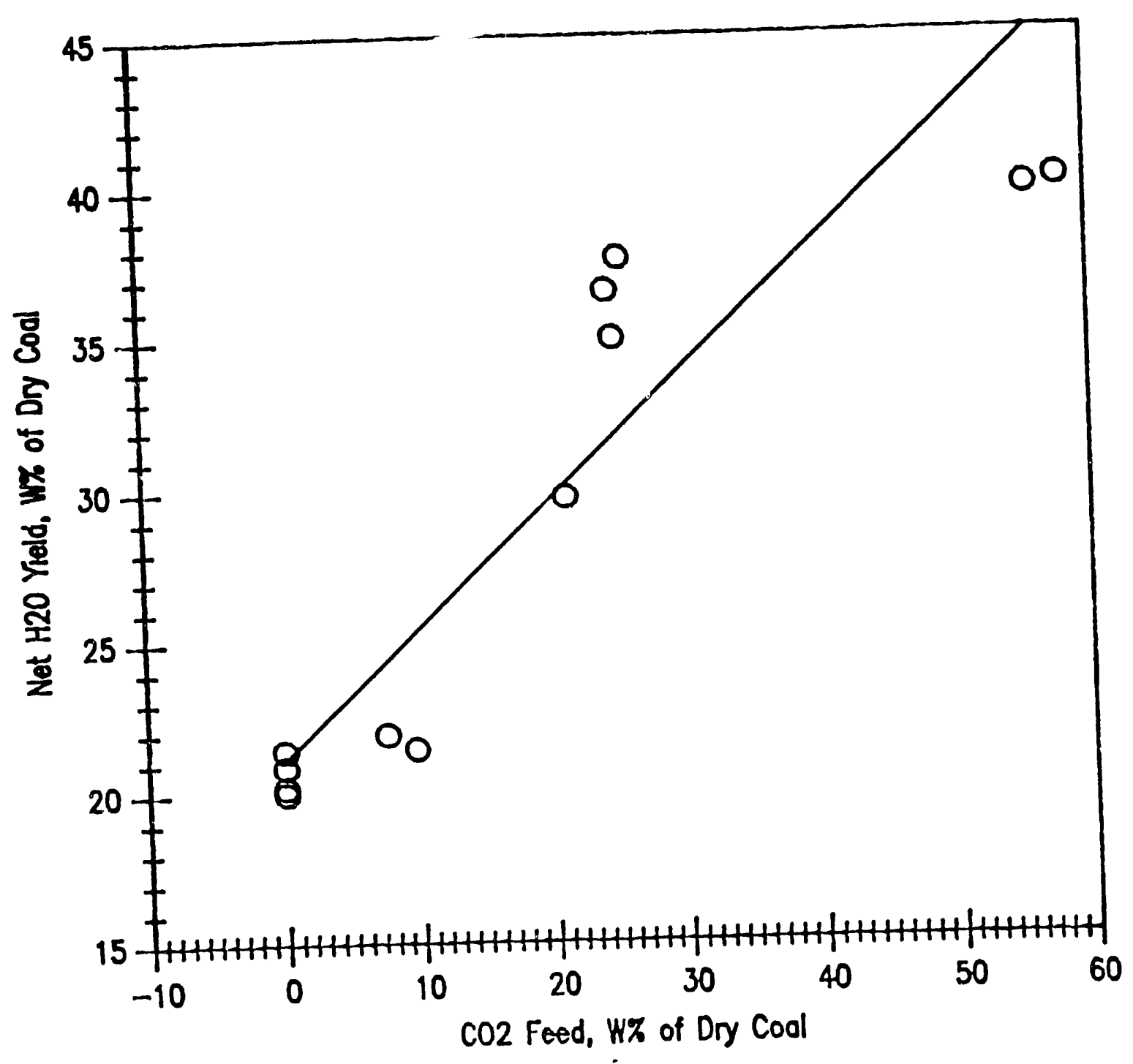


FIGURE 11

\section{CH4 YIELD VS C02 FED \\ CTSL Run CC-13 - Collected Yields}

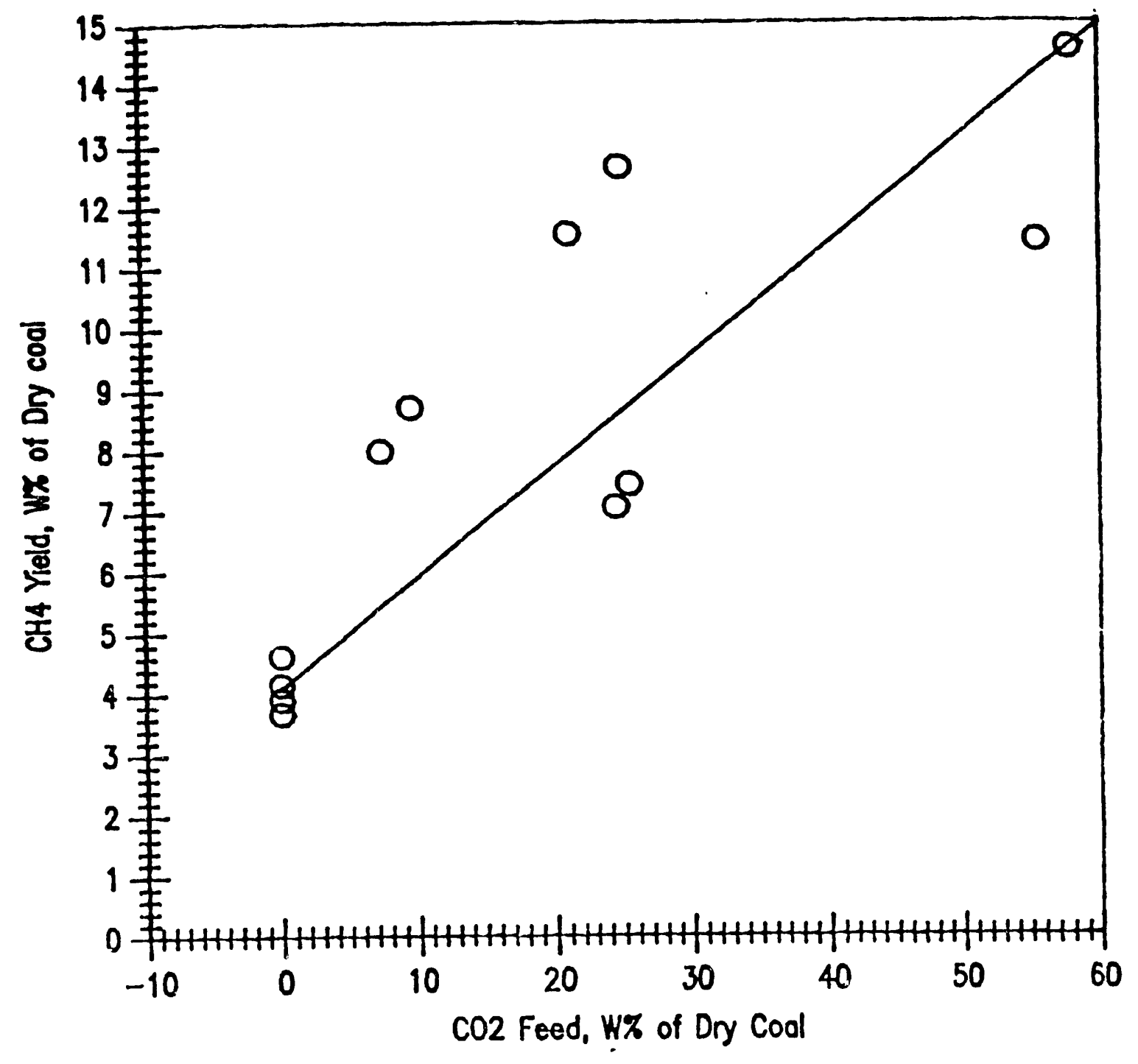


FIGURE 12

\section{CO YIELD VS C02 FED \\ CTSL Run CC-13 - Collected Yields}

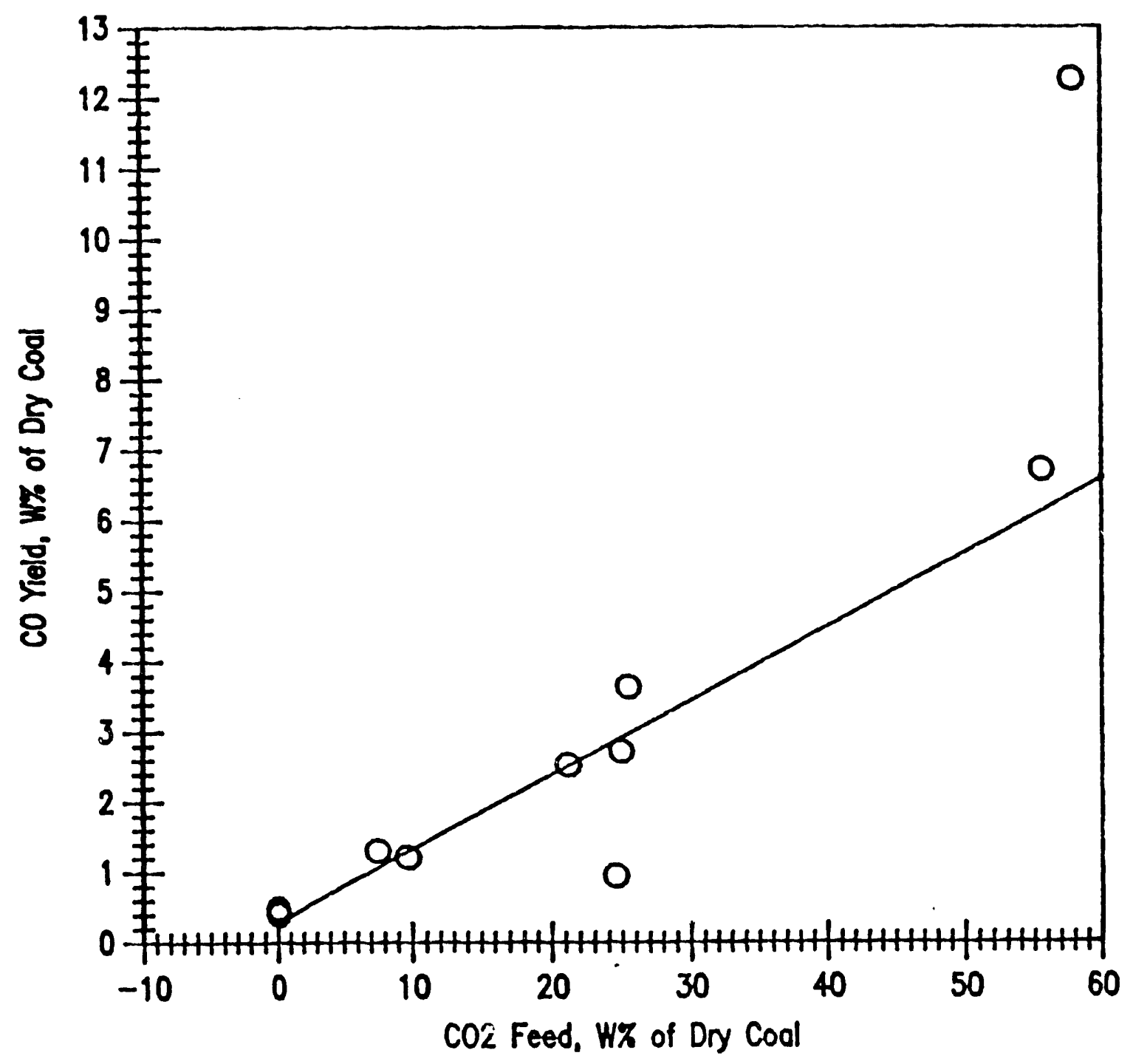


FIGURE 13

\section{C2-C4 GAS YIELD VS CO2 FED \\ CTSL Run CC-13 - Collected Yields}

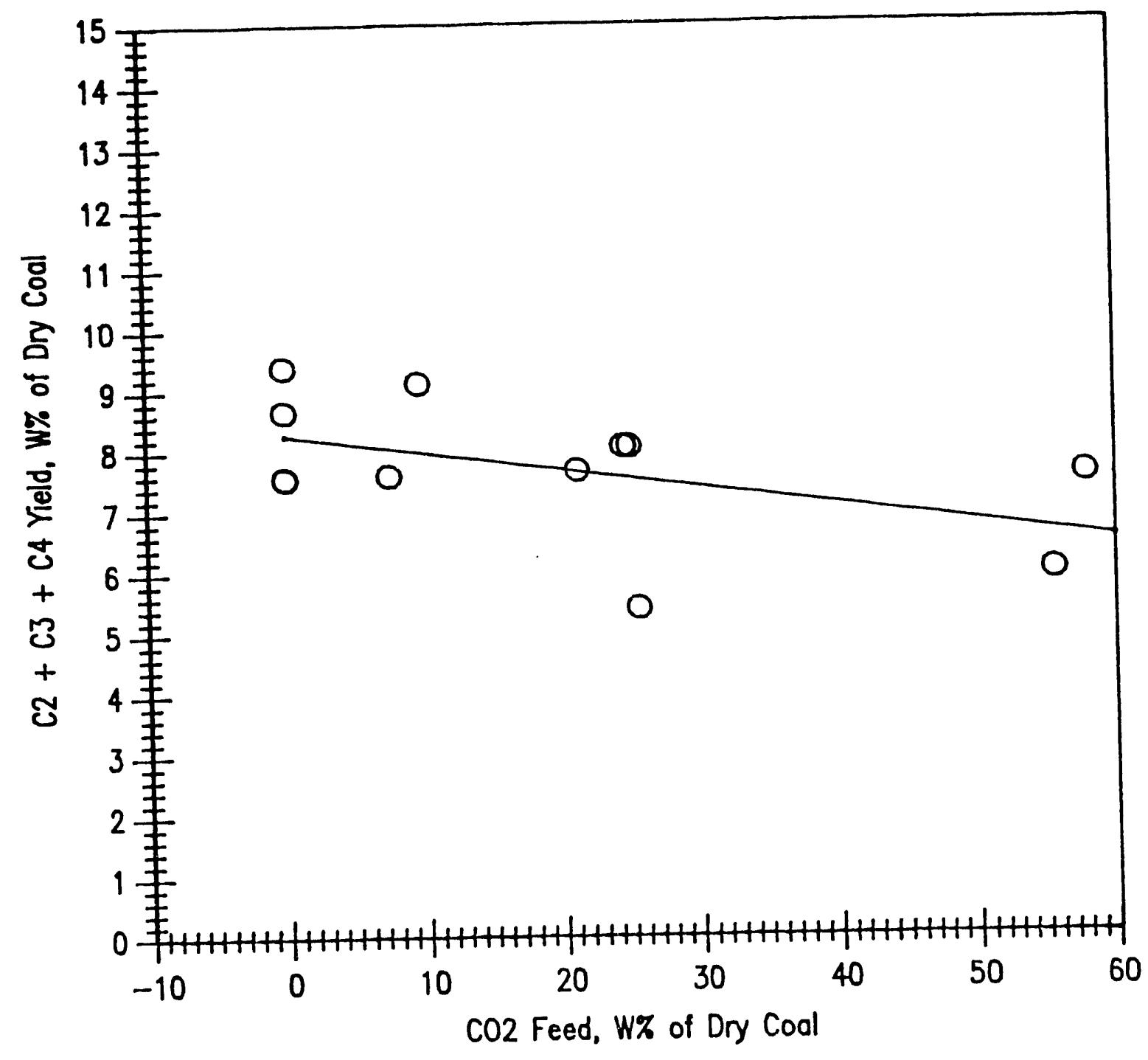




\section{TASK 4 - MINI-PDU SCALE-UP}

\section{Preparations}

Plans are being formulated to test the Black Thunder feed coal prepared at Empire Coke in Alabama where the coal for the Wilsonville, Alabama operation is prepared. Start-up solvent will be obtained from the Wilsonville plant.

Orders have been placed for Shell 317 catalyst in both $1 / 32$ and $1 / 16^{\prime \prime}$ diameters.

The British Coal Corporation Filtration Process utilizing a U.S. vertical leaf pressure filter will be installed for liquid-solid separation. 


\section{TASK 5 - TECHNICAL ASSESSMENT}

\section{MODELLING}

\section{Residuum Yields in Microautoclave Tests of Coals}

The results of coal evaluation tests during the current program of various coals have been reviewed comparing the residual oil yields of the catalytic and thermal (non-catalytic) tests. The conditions for these tests have been 2,000 psig $\mathrm{H}_{2}$ pressure, 30 minutes residence time, $800^{\circ} \mathrm{F}, 4$ grams of coal liquefaction derived distillate oil per gram of coal, and 1 gram presulfided S-317 catalyst per gram of coal. This analysis indicated apparently significant differences in residual oil yield for various coals, and in the catalytic and thermal yields, as summarized in the following table:

Resid. YId, W\% of Conv. Coal-

\begin{tabular}{cccc}
\hline Thermal Test & Catalyst Test & & Ratio \\
46.4 & 32.1 & 0.69 \\
37.1 & 23.2 & 0.63 \\
50.2 & 25.4 & 0.51 \\
38.1 & 20.0 & 0.52
\end{tabular}

These results are the averages of 37 pairs of the thermal and catalytic tests, 12 with the Black Thunder Coal, 14 with the Illinois Coal (cleaned and uncleaned), and 11 with six other Sub-bituminous coals.

Statistically, the higher residual oil yields with Illinois No. 6 coal than Black Thunder coal has a confidence level of $99.0 \%$. The higher residual oil yield for thermally treated (at $400-600^{\circ} \mathrm{F}$ ) Black Thunder coal compared to the untreated coal has a statistical confidence level of $99.5 \%$, but the difference in catalytic results is not significantly different. Nominally, the thermal treatment does increase the potential for residual oil yield, but this is readily overcome in the catalytic operation. The relative residual oil yields of catalytic and thermal operation differ from coal to coal on the average, but the variability of the data (the standard error of the yields was $5.6 \%$ ) indicates only a $40 \%$ confidence level in the significance of such apparent differences.

A similar comparison was made of the results for lllinois No. 6 and Ohio $5 / 6$ coals in tests made during the previous program. Here, the test program included tests at $750^{\circ} \mathrm{F}$ and $825^{\circ} \mathrm{F}$ in addition to the tests at $800^{\circ} \mathrm{F}$, so that the correlation against severity could be developed. Figure 1 compares the thermal and catalytic results for the two coals, by plotting the residual oil yield (logarithmic scale) and against nominal thermal severity, STTU (test time adjusted to equivalent time at $840^{\circ} \mathrm{F}$, using an Arrhenius activation energy of $89,500 \mathrm{Btu} / \mathrm{lb}$ mole). 
In Figure 14, the residual oil yields in the tests with the Ohio Coal was generally higher than those with the Illinois Coal at comparable condition. The trends of residual oil yields in the thermal tests against severity correspond reasonably closely to a linear trend of the logarithm of the residual oil formation against severity (STTU) indicating the activation energy used in the calculation of STTU is appropriate.

Further interpretation was attempted with a very simple kinetic model, which assumed that the conversion reaction of the coal is very rapid and produces a fixed proportion of the residual oil subject to secondary reaction. This primary quantity of residual oil then undergoes secondary reaction following simple, single species, first order kinetics. With this model, extrapolation of the thermal tests results to a 0.0 value of STTU indicates the amount of primary residual oil formation, with a value of about $72 \%$ of converted coal for the Ohio Coal, and of about $62 \%$ for the Illinois coal. The lower yields of residual oil in the catalytic tests indicate additional reaction rate because of the catalyst tests, and permit calculation of apparent relative reaction rate constants for the thermal and catalytic tests.

The following apparent first order rate constants (1/hours) for the various tests were then calculated:

\begin{tabular}{|c|c|c|c|c|}
\hline & \multicolumn{2}{|c|}{ Ohio Coal } & \multicolumn{2}{|c|}{ Illinois Coal } \\
\hline & Thermal & Catalytic & Thermal & Catalytic \\
\hline $\begin{array}{c}\text { Temp., 'F (STTU) } \\
750(2.3) \\
800(10.0) \\
825(20.0)\end{array}$ & $\begin{array}{c}0.060 \\
0.860^{\star} \\
0.538\end{array}$ & $\begin{array}{l}1.012 \\
1.341 \\
1.976\end{array}$ & $\begin{array}{l}0.070 \\
0.340 \\
0.618\end{array}$ & $\begin{array}{l}0.926 \\
1.444 \\
1.752\end{array}$ \\
\hline
\end{tabular}

* Disregarded

Taking the increment between the catalytic result and the thermal result as the contribution of the catalyst itself indicates a value of $1.13-1.44 \mathrm{hr}^{-1}$ at $825^{\circ} \mathrm{F}$, with an activation energy of about $12,000-17,000 \mathrm{Btu} / \mathrm{lb}$ mole for the catalytic rate constant. 
FIGURE 14
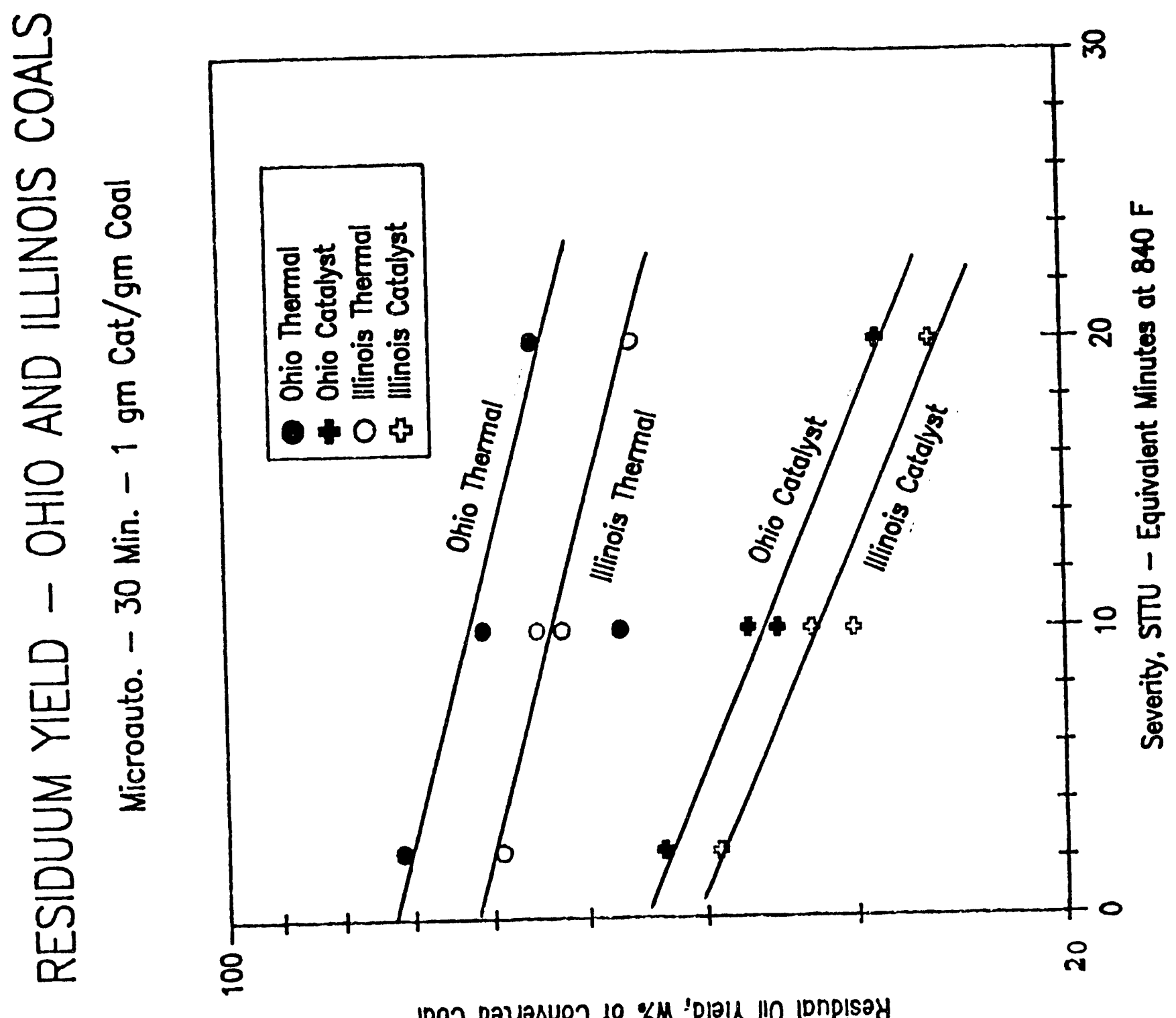

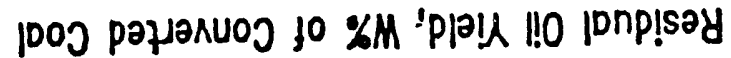




\section{TASK 6 - ADDMINISTRATION}

In the balance of the current contract the PDU scale-up demonstration run remains. Topical reports for the Bench-Scale and Laboratory-Scale Studies are being prepared.

A paper entitled "CTSLTM Catalytic Two-Stage Liquefaction Coupled with Coal Cleaning" was prepared for presentation at the 201st National ACS Meeting in Atlanta Georgia on April 14-19, 1991.

The attached schedule shows the run activities for the remainder of the contract. 


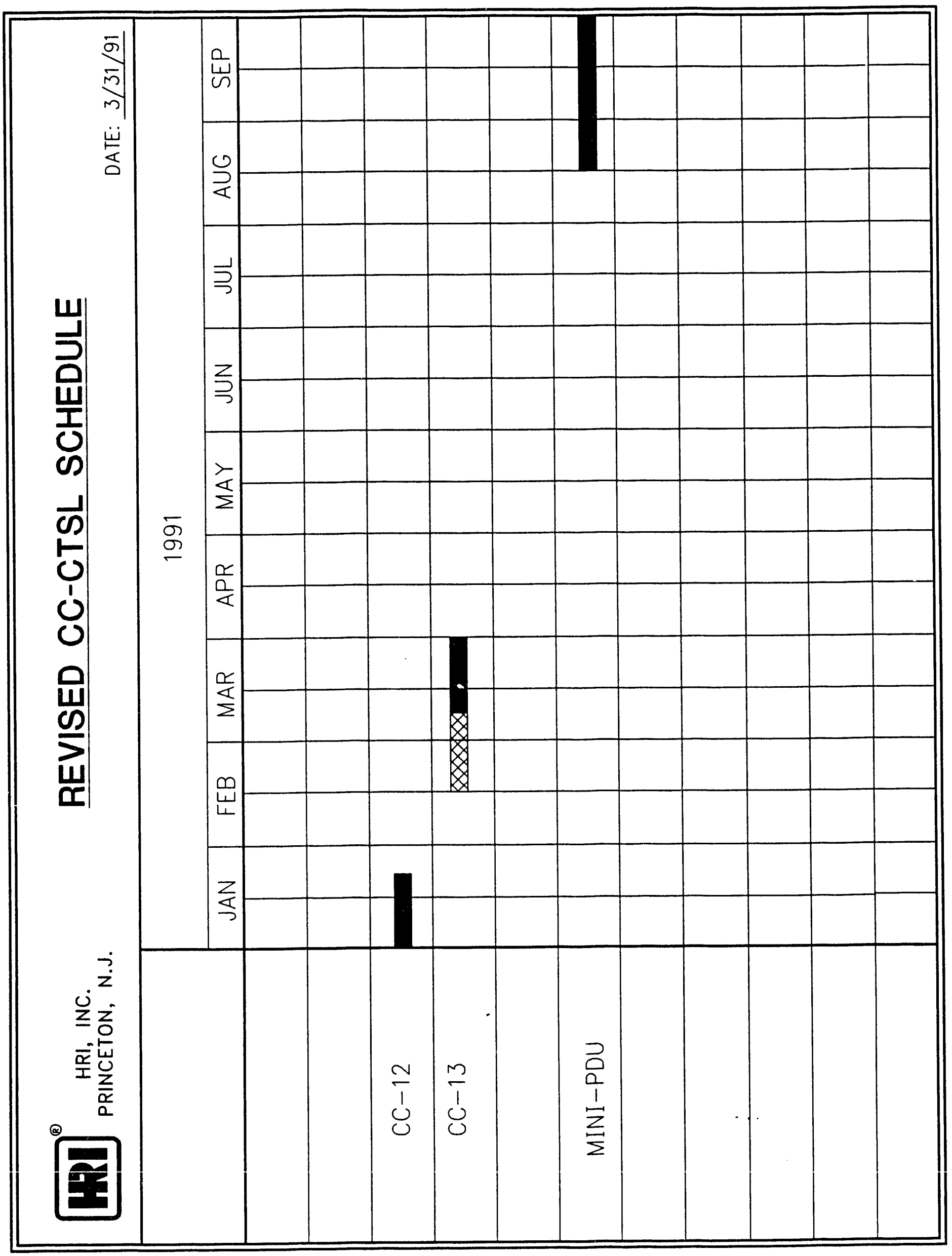



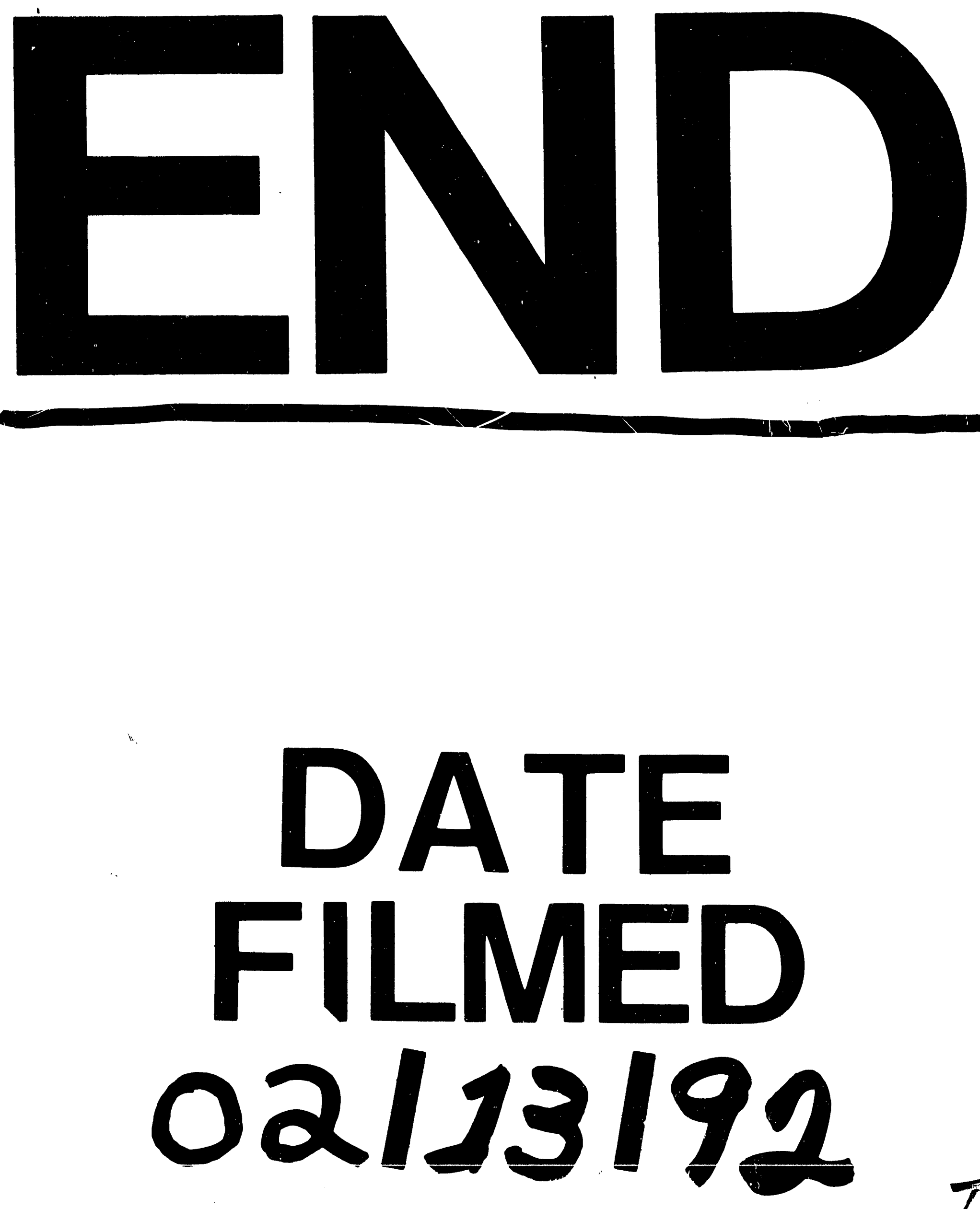
